\title{
Measurement report: Ice nucleating abilities of biomass burning, African dust, and sea spray aerosol particles over the Yucatán Peninsula
}

\author{
Fernanda Córdoba $^{1,2} \star$, Carolina Ramírez-Romero ${ }^{1,3} \star$, Diego Cabrera ${ }^{1}$, Graciela B. Raga ${ }^{1}$, Javier Miranda ${ }^{4}$, \\ Harry Alvarez-Ospina ${ }^{5}$, Daniel Rosas ${ }^{6}$, Bernardo Figueroa ${ }^{7}$, Jong Sung Kim ${ }^{8}$, Jacqueline Yakobi-Hancock ${ }^{8}$, \\ Talib Amador $^{6}$, Wilfrido Gutierrez ${ }^{1, \boldsymbol{t}}$, Manuel García ${ }^{1}$, Allan K. Bertram ${ }^{9}$, Darrel Baumgardner ${ }^{10}$, and \\ Luis A. Ladino ${ }^{1}$ \\ ${ }^{1}$ Centro de Ciencias de la Atmósfera, Universidad Nacional Autónoma de México, Mexico City, Mexico \\ ${ }^{2}$ Posgrado en Ciencias Químicas, Universidad Nacional Autónoma de México, Mexico City, Mexico \\ ${ }^{3}$ Posgrado en Ciencias de la Tierra, Universidad Nacional Autónoma de México, Mexico City, Mexico \\ ${ }^{4}$ Instituto de Física, Universidad Nacional Autónoma de México, Mexico City, Mexico \\ ${ }^{5}$ Facultad de Ciencias, Universidad Nacional Autónoma de México, Mexico City, Mexico \\ ${ }^{6}$ Facultad de Química, Universidad Autónoma de Yucatán, Mérida, Mexico \\ ${ }^{7}$ Laboratorio de Ingeniería y Procesos Costeros, Instituto de Ingeniería, Universidad Nacional Autónoma de México, \\ Sisal, Yucatán, Mexico \\ ${ }^{8}$ Department of Community Health and Epidemiology, Dalhousie University, Halifax, NS, Canada \\ ${ }^{9}$ Department of Chemistry, University of British Columbia, Vancouver, BC, Canada \\ ${ }^{10}$ Droplet Measurement Technologies, LLC, Colorado, USA \\ ^ These authors contributed equally to this work. \\ $\boldsymbol{t}_{\text {deceased }}$
}

Correspondence: Luis A. Ladino (luis.ladino@atmosfera.unam.mx)

Received: 27 July 2020 - Discussion started: 14 August 2020

Revised: 17 February 2021 - Accepted: 18 February 2021 - Published: 23 March 2021

\begin{abstract}
Most precipitation from deep clouds over the continents and in the intertropical convergence zone is strongly influenced by the presence of ice crystals whose formation requires the presence of ice nucleating particles (INPs). Although there are a large number of INP sources, the ice nucleating abilities of aerosol particles originating from oceans, deserts, and wildfires are poorly described at tropical latitudes. To fill this gap in knowledge, the National Autonomous University of Mexico micro-orifice uniform deposit impactor droplet freezing technique (UNAM-MOUDIDFT) was constructed to measure the ice nucleating activity of aerosol samples that were collected in Sisal and Mérida, Yucatán (Mexico) under the influence of cold fronts, biomass burning (BB), and African dust (AD) intrusions during five short-term field campaigns between January 2017 and July 2018.
\end{abstract}

The three different aerosol types were distinguished by their physicochemical properties. Marine aerosol (MA), BB, and $\mathrm{AD}$ air masses were found to contain INPs; the highest concentrations were in $\mathrm{AD}$ (from 0.071 to $36.07 \mathrm{~L}^{-1}$ at temperatures between -18 and $-27^{\circ} \mathrm{C}$ ), followed by MA (from 0.068 to $18.90 \mathrm{~L}^{-1}$ at temperatures between -15 and $-28^{\circ} \mathrm{C}$ ) and $\mathrm{BB}$ (from 0.063 to $10.21 \mathrm{~L}^{-1}$ at temperatures between -20 and $-27^{\circ} \mathrm{C}$ ). However, MA had the highest surface active site densities $\left(n_{\mathrm{s}}\right)$ between -15 and $-30^{\circ} \mathrm{C}$. Additionally, supermicron particles contributed more than $72 \%$ of the total INP concentration independent of aerosol type. 


\section{Introduction}

Approximately $60 \%$ of the Earth's surface is covered by clouds at any time; however, a lack of detailed knowledge about the aerosol-cloud interactions introduces large uncertainties in projections of climate change (Lohmann and Feichter, 2005; Boucher et al., 2013). Globally, the precipitation in the intertropical convergence zone (ITCZ) and over the continents is dominated by cold rain; therefore, it is very important to fully understand the formation of ice in clouds (Mülmenstädt et al., 2015). Primary ice particle formation takes place in the atmosphere via homogeneous and heterogeneous ice nucleation. Homogeneous ice nucleation typically occurs at temperatures below $-38^{\circ} \mathrm{C}$ and relative humidities with respect to ice $\left(\mathrm{RH}_{\mathrm{i}}\right)$ above $140 \%$ (Knopf et al., 2011; Kanji et al., 2017). In contrast, heterogeneous nucleation, in which ice nucleating particles (INPs) promote phase transition, occurs at temperatures warmer than $-38^{\circ} \mathrm{C}$ and lower $\mathrm{RH}_{\mathrm{i}}$ than those required for homogeneous nucleation (Kanji et al., 2017). Although there are several modes through which ice particles can form heterogeneously (i.e., deposition nucleation, pore-condensation freezing, immersion freezing, condensation freezing, and contact freezing), immersion freezing has been reported as the most important ice nucleation mode for mixed-phase clouds (Knopf et al., 2011; Murray et al., 2012).

The presence of INPs in clouds affects their microphysical properties, lifetime, precipitation formation, and the planetary radiative balance (DeMott et al., 2003, 2010; Boucher et al., 2013; Kanji et al., 2017). At temperatures higher than $-38^{\circ} \mathrm{C}, 1$ in $10^{6}$ (or fewer) atmospheric aerosol particles can act as INPs (DeMott et al., 2010; Lohmann et al., 2016). Although it remain partially unclear which physicochemical properties make an aerosol particle a good INP, its size (diameter $>0.5 \mu \mathrm{m}$ ), crystal structure (similar to the ice lattice structure), chemical composition (hygroscopicity and ability to form hydrogen bonds), insolubility (solid surface for the ice embryo formation), and the presence of active sites have been reported as key factors (Pruppacher and Klett, 1997; Murray et al., 2012; Kanji et al., 2017). As summarized by Kanji et al. (2017), aerosol particles, such as mineral and desert dust, crystalline salts, volcanic ash, organic and glassy particles, metallic particles, biomass and fossil combustion particles, marine aerosol (MA), and biological particles, have all been shown to act as INPs under varying thermodynamic conditions as a function of the ice nucleation mode. A short summary of the main results of the ice nucleating abilities found for mineral dust, biomass burning (BB), and MA particles in the immersion freezing mode is provided below. Note that a direct comparison of the INP concentrations reported in different studies needs to be considered carefully as there are factors associated with each technique or method, such as sampling volume, droplet size, aerosol loading, aerosol particle size range, and temperature range, among others, that could be influencing specific results.
Mineral dust is mainly composed of clays (e.g., kaolinite, montmorillonite, illite), feldspars, and quartz, among others (e.g., Zimmermann et al., 2008; Ardon-Dryer and Levin, 2014). The ice nucleating abilities of pure minerals, clays, and surrogates of natural mineral dust particles have been previously evaluated in the immersion freezing mode (e.g., Marcolli et al., 2007; Augustin-Bauditz et al., 2014; Lüönd et al., 2010; Murray et al., 2011; Wheeler et al., 2015; Harrison et al., 2019). These studies found that mineral dust particles will catalyze ice formation at temperatures as high as $-15.2^{\circ} \mathrm{C}$. Boose et al. (2016) analyzed 15 ambient mineral dust samples, including some collected after they were transported from distant sources. The authors reported that the efficient ice nucleating abilities of those samples were related to the presence of $\mathrm{K}$-feldspar, which is in agreement with earlier results reported by Atkinson et al. (2013). Boose et al. (2016) also show that airborne dust samples transported from distant sources had lower ice nucleation activity likely due to particle aging. Ardon-Dryer and Levin (2014) evaluated the ice nucleating abilities of mineral dust from the eastern Mediterranean region via immersion freezing and found that INP concentrations varied from 0.16 to $234 \mathrm{~L}^{-1}$ at temperatures between -11.8 and $-28.9^{\circ} \mathrm{C}$. Reicher et al. (2019) found similar INP concentrations (from 0.1 to $1000 \mathrm{~L}^{-1}$ ) in the same region, during dust storms, and at temperatures ranging from -18.2 to $-38.2{ }^{\circ} \mathrm{C}$. Price et al. (2018) reported INP concentrations from 0.1 to $100 \mathrm{~L}^{-1}$ at -12 and $-23{ }^{\circ} \mathrm{C}$ under dusty conditions around Cape Verde, Africa, while Gong et al. (2020a) found INP concentrations between 0.0003 and $0.2 \mathrm{~L}^{-1}$ at temperatures between -5 and $-24^{\circ} \mathrm{C}$ under low dust emissions on one of the Cape Verde islands.

A total of 9 of the 21 different biomass fuels tested by Petters et al. (2009) produced INPs, with swamp sawgrass smoke identified as the most efficient fuel reporting an INP fraction of $\approx 1: 100$ particles. Umo et al. (2015) evaluated the ice nucleating activity of coal fly ash (CFA), coal bottom ash, domestic bottom ash, and wood bottom ash. CFA was found to be the most efficient with a $T_{50}$ (the temperature at which $50 \%$ of the droplets freeze) of around $-16^{\circ} \mathrm{C}$. The authors identified particle morphology and chemical composition as the key physicochemical properties controlling the ice nucleating abilities of the evaluated BB particles. In controlled laboratory experiments, Levin et al. (2016) analyzed 22 different biomass fuels and found that the INP concentrations ranged between $10^{2}$ and $10^{4}$ per liter at $-30^{\circ} \mathrm{C}$. They also observed increased INP concentrations for intense flaming combustion (i.e., > 0.95). Prenni et al. (2012) found that INP concentrations from wildfires and prescribed fires in Colorado and Wyoming (United States) ranged between 3.4 and $90 \mathrm{~L}^{-1}$ at $-30{ }^{\circ} \mathrm{C}$. Likewise, McCluskey et al. (2014) found that mean INP concentrations during prescribed burns varied from 6.36 to $16.7 \mathrm{~L}^{-1}$ at $-30^{\circ} \mathrm{C}$ in Colorado and from 0.64 to $34.03 \mathrm{~L}^{-1}$ between -22 and $-30^{\circ} \mathrm{C}$ in Georgia. However, McCluskey et al. (2014) showed that INP concentrations were higher during wildfires in Colorado (i.e., 
Hewlett wildfire and High Park wildfire) with mean values of 15.90 to $79.43 \mathrm{~L}^{-1}$ (between -22 and $-30^{\circ} \mathrm{C}$ ) and 7.18 to $75.98 \mathrm{~L}^{-1}$ (between -22 and $-31^{\circ} \mathrm{C}$ ). It is important to note that aerosol particles emitted by BB contain smoke and ash (Kanji et al., 2017). In general, BB particles are enriched in organic compounds and to a lesser extent trace metals (Saarikoski et al., 2007). Jahn et al. (2020) showed that $\mathrm{BB}$ particles may contain calcite, sylvite, dolomite, potassium sulfate, and quartz. However, the mineral composition will differ depending on the combustion conditions, biomass source, and the chemical composition, among others.

Several field campaigns have been conducted to evaluate the ice nucleating abilities of aerosol particles in marine environments. It has been shown that the composition of the MA strongly depends on the particle size, with the highest organic content found in submicron particles (O'Dowd et al., 2004; Prather et al., 2013; Quinn et al., 2015). Bigg (1973) collected aerosol samples in Australia, Schnell and Vali (1975) in Huntington Beach (California, US), in the Caribbean off Nassau (Bahamas), and in Vancouver and Nova Scotia (Canada), Rosinski et al. (1987) over the Pacific Ocean, and Rosinski et al. (1988) in the Gulf of Mexico (GoM). More recently, the ice nucleating abilities of particles present in the Arctic sea surface microlayer (Wilson et al., 2015; Irish et al., 2017, 2019) and the Arctic ambient aerosol were evaluated (DeMott et al., 2016; Creamean et al., 2018; Wex et al., 2019). Similar studies were performed over the eastern Mediterranean by Gong et al. (2019), over the Southern Ocean by McCluskey et al. (2018) and Welti et al. (2020), over the North Atlantic by Wilbourn et al. (2020), and over the tropical Atlantic by DeMott et al. (2016), Welti et al. (2018), Ladino et al. (2019), Ladino et al. (2020), and Gong et al. (2020a). Welti et al. (2020) presented an analysis of the INP concentrations on ship-based measurements for different zones in the Arctic, Atlantic, Pacific, and Southern oceans. The different climatic zones covered in the Welti et al. (2020) study were divided depending on the latitude. For the tropical zone $\left(23.5^{\circ} \mathrm{N}-23.5^{\circ} \mathrm{S}\right)$, the authors report that the concentrations of INPs vary between 0.001 and $0.1 \mathrm{~L}^{-1}$ at temperatures from -5 to $-25^{\circ} \mathrm{C}$ and between 0.1 and $10^{5} \mathrm{~L}^{-1}$ at lower temperatures, i.e., from -24 to $-38^{\circ} \mathrm{C}$. It is important to note that in some of the aforementioned studies, onset freezing temperatures as high as $-3^{\circ} \mathrm{C}$ were reported which were associated with marine organic material likely of biological origin.

Aerosol particles can be transported over long distances far from their emission sources (e.g., Griffin et al., 2001; Taylor, 2002; Wu et al., 2004; Prenni et al., 2009). For example, DeMott et al. (2003), Prospero and Lamb (2003), Prospero and Mayol-Bracero (2013), and Ramírez-Romero et al. (2021) showed how mineral dust particles from the Saharan desert could reach the Caribbean region, the United States, and Mexico. The highest probability for mineral dust to reach the Caribbean and Mexico occurs during the mid-summer drought (MSD), a period of a relative minimum in precip- itation within the rainy season typically between mid-July and mid-August. Similarly, Peppler et al. (2000) and Saide et al. (2015) showed how BB particles from Central America and southern Mexico could impact the Yucatán Peninsula, Mexico. As shown by Ríos and Raga (2018), there is a clear BB seasonality in Mexico and Central America from December to June with the largest burned areas between April and May. Finally, the arrival of air masses to southern Mexico behind cold fronts has also been documented (DiMego et al., 1976; Cavazos, 1997), which are characterized by low temperatures, dry conditions, and strong winds flowing over the GoM. These bring marine aerosol particles into the Yucatán Peninsula, as shown by Ladino et al. (2019). During longrange travel, the physicochemical properties (e.g., size, composition, morphology, hygroscopicity, etc.) of the transported aerosol particles can be modified due to atmospheric aging that likely affects their ice nucleating abilities (e.g., Kanji et al., 2017).

The majority of the field studies related to INPs have been carried out at middle and high latitudes with a limited number of studies in the tropics. As the tropical regions have significantly different characteristics than higher latitudes (e.g., flora, fauna, marine biological activity, sea surface temperature, air temperature, relative humidity, $\mathrm{RH}$, cloud cover, atmospheric circulation), there is a compelling need to improve the current understanding of the role of aerosol particles emitted at tropical latitudes as they impact cloud formation (Yakobi-Hancock et al., 2014). Given that Mexico is annually impacted by aerosol particles transported from Africa, North America, and Central America, the present study evaluates the ice nucleating abilities of these three types of aerosol particles.

\section{Methodology}

\subsection{Sampling location}

Five short-term field campaigns were carried out between January 2017 and July 2018, three in Mérida $\left(20.98^{\circ} \mathrm{N}\right.$, $\left.89.64^{\circ} \mathrm{W}\right)$ and two in Sisal $\left(21.16^{\circ} \mathrm{N}, 90.04^{\circ} \mathrm{W}\right)$, as part of the African Dust and Biomass Burning Over Yucatán (ADABBOY) project. Both sites are located in the Yucatán Peninsula (Fig. 1) in southeastern Mexico. The Yucatán Peninsula is surrounded by the GoM in the north and west, the Caribbean Sea in the east, and Central America in the south. Most of the peninsula (i.e., $86 \%$ ) experiences a warm, tropical wet climate, while the remaining $14 \%$ has a dry and semi-dry climate. The annual average temperature and $\mathrm{RH}$ are $26^{\circ} \mathrm{C}$ and $79 \%$, respectively (INEGI, 2019). Its soil is karstic, in which the principal components are limestone, dolomite, and gypsum (Herrera-Silveira et al., 2004b).

Mérida, the capital of Yucatán State located about $35 \mathrm{~km}$ inland from the coast of the GoM, has a population of 892363 (INEGI, 2015). The main industries are tourism, 


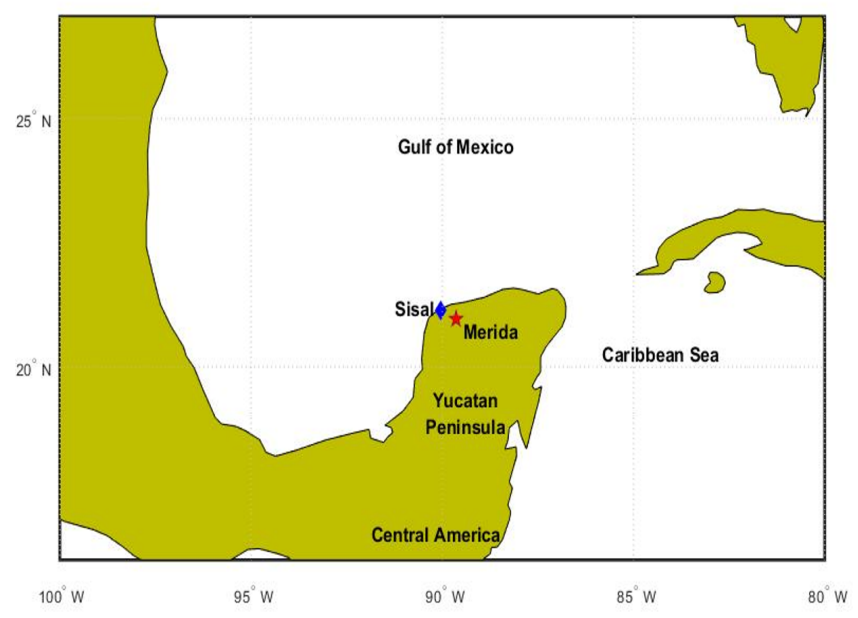

Figure 1. Map showing the Yucatán Peninsula and the sampling locations, i.e., Sisal (blue diamond) and Mérida (red star).

manufacturing, textiles, and commerce (García de Fuentes and Morales, 2000). The city has an average temperature of $25^{\circ} \mathrm{C}$ and an annual accumulated precipitation of about $900 \mathrm{~mm}$ (INEGI, 2017). The sampling site in Mérida was located on the rooftop of the school of chemistry of the Universidad Autónoma de Yucatán (SC-UADY), located in the central-western part of the city, $3 \mathrm{~km}$ from downtown.

Sisal is located $49 \mathrm{~km}$ from Mérida and has 1837 inhabitants (INEGI, 2010). It is a small coastal village, most people work in fishing-related activities, and there are no nearby industrial emissions (Santoyo, 2017). The mean temperature and $\mathrm{RH}$ are $27^{\circ} \mathrm{C}$ and $80.8 \%$, respectively. Sisal is affected yearly by cold fronts between November and January and by convective storms and precipitation from the end of April to October (Santoyo, 2017). The aerosol sampling took place on the rooftop of the engineering institute of the Universidad Nacional Autónoma de México (EI-UNAM), which is $50 \mathrm{~m}$ from the shoreline. The dates of the sampling periods for Mérida and Sisal are shown in Table 1. A subset of the samples (those with the full size range available, i.e., from 0.32 to $10 \mu \mathrm{m}$ ) collected during the five campaigns was chosen for this study, as summarized in Table S1.

The presence of $\mathrm{BB}$ particles and the intrusions of $\mathrm{AD}$ into the Yucatán Peninsula have been previously documented (e.g., Yokelson et al., 2009; Kishcha et al., 2014; Ríos and Raga, 2018; Raga et al., 2021; Trujano-Jiménez et al., 2021; Ramírez-Romero et al., 2021). Ríos and Raga (2018) reported that within the BB season, the maximum fire density is observed in April. Likewise, Kishcha et al. (2014), Raga et al. (2021), and Ramírez-Romero et al. (2021) indicate that July is the period with the highest likelihood for the $\mathrm{AD}$ influx to the western Caribbean within the MSD. Therefore, April and July were chosen as the sampling periods to capture the presence of $\mathrm{BB}$ and $\mathrm{AD}$ particles in Mérida, respectively.
Table 1. Summary of the sampling periods, the instrumentation used, and the type of collected samples (for chemical composition and INP analysis) from Mérida and Sisal during 2017 and 2018. $\mathrm{MA}, \mathrm{BB}$, and $\mathrm{AD}$ refer to marine aerosol, biomass burning, and African dust, respectively. The ${ }^{\mathrm{a}},{ }^{\mathrm{b}}$, and ${ }^{\mathrm{c}}$ denote the samples collected for chemical analysis, samples collected for INP analysis, and samples not collected during this period, respectively.

\begin{tabular}{|c|c|c|c|}
\hline Aerosol type & Place & 2017 & 2018 \\
\hline MA & Sisal & $\begin{array}{l}21 \text { Jan-2 Feb } \\
\text { LasAir II 310A } \\
\text { MOUDI 100NR } \\
\text { MOUDI 100R }\end{array}$ & $\mathrm{c}$ \\
\hline $\mathrm{BB}$ & Mérida & $\begin{array}{l}13 \text { Apr-31 May } \\
\text { LasAir II } 310 \mathrm{~A} \\
\text { FH62C14 } \\
\text { Partisol } 2025 \mathrm{i}^{\mathrm{a}} \\
\text { MOUDI } 100 \mathrm{R}^{\mathrm{b}}\end{array}$ & $\begin{array}{l}26 \mathrm{Mar}-8 \mathrm{Apr} \\
\text { LasAir II 310A } \\
\text { FH62C14 } \\
\text { Partisol 2025i }{ }^{\mathrm{a}} \\
\text { MOUDI 100R }\end{array}$ \\
\hline \multirow[t]{2}{*}{$\mathrm{AD}$} & Sisal & $\mathrm{c}$ & $\begin{array}{l}3 \text { Jul-16 Jul } \\
\text { LasAir II 310A } \\
\text { MiniVol }^{\mathrm{a}} \\
\text { MOUDI 100R }^{\mathrm{b}}\end{array}$ \\
\hline & Mérida & $\mathrm{c}$ & $\begin{array}{l}3 \text { Jul-16 Jul } \\
\text { LasAir III 310C } \\
\text { MiniVol }^{\mathrm{a}} \\
\text { MOUDI 100R }\end{array}$ \\
\hline
\end{tabular}

Given that the Yucatán Peninsula is encircled by the GoM, MA is ubiquitous throughout the Peninsula. Therefore, the MA composition was assessed in the remote coastal village of Sisal between January and February, a time of the year when the presence of particles such as BB and AD are least likely.

\subsection{Instrumentation}

\subsubsection{Ice nucleating particles}

The evaluation of the ice nucleating abilities of the ambient aerosol particles consists of three steps: (i) collection of the particles, (ii) activation with the droplet freezing technique (DFT), and (iii) calculation of the INP concentration as a function of temperature and particle size.

\section{Collection of aerosol particles}

Aerosol particles were collected by inertial impaction on hydrophobic glass coverslips of $22 \mathrm{~mm} \times 22 \mathrm{~mm}$ (HR3-215, Hampton Research) using a micro-orifice uniform deposit impactor (MOUDI 100R; MSP), as shown in Fig. 2a. To secure the glass coverslips on the micro-orifice uniform deposit impactor (MOUDI) stages, substrate holders were used as reported by Mason et al. (2015a). The MOUDI has eight stages to separate particles as a function of their aerodynamic diameter (cut sizes of $0.18,0.32,0.56,1.0,1.8,3.2$, 
5.6, and $10.0 \mu \mathrm{m})$. The flow rate was set to $30.0 \mathrm{~L} \mathrm{~min}^{-1}$ for the five campaigns, except for Sisal 2018, with a flow rate of $25.8 \mathrm{~L} \mathrm{~min}^{-1}$. The sampling period was typically $6 \mathrm{~h}$ from 08:00 to 14:00 (local time; all times are in central standard time); however, on some specific days, more than one sample per day was collected. After each sampling, the glass coverslips were stored in petri dishes for between 3 and 22 months at $4{ }^{\circ} \mathrm{C}$ prior to their analysis with the DFT in Mexico City (Fig. 2a). As recently highlighted by Beall et al. (2020), the temperature and the length of the storage can impact the ice nucleation abilities of MA samples. Although, this was not evaluated in the present study, future studies will evaluate how the storage procedure impacts results.

\section{The UNAM-DFT}

The DFT has been employed in various studies to evaluate the ability of aerosol particles to act as INPs via immersion freezing (e.g., Koop et al., 2000; Iannone et al., 2011; Mason et al., 2015a, b; Wheeler et al., 2015; Si et al., 2018; Irish et al., 2019). A DFT was built in the Micro- and Mesoscale Interactions Laboratory of the Atmospheric Science Center at UNAM based on the design described in Mason et al. (2015a). The results delivered by the Mason et al. (2015a) MOUDI-DFT were compared against those reported by the Colorado State University Continuous Flow Diffusion Chamber (CSU-CFDC). As shown in DeMott et al. (2017), the median INP concentrations from both devices were in good agreement.

The newly built DFT consists of four components: (i) cold stage, (ii) humid/dry air system, (iii) optical microscope with video recording system, and (iv) data acquisition system (Fig. 3).

The cold stage consists of a sample holder, a cooling block, and a heating block all aligned and stacked on top of each other with the sample holder at the top and the cooling block at the bottom (Fig. S1a). The cooling block is made of stainless steel $(4 \mathrm{~cm} \times 4 \mathrm{~cm} \times 2 \mathrm{~cm})$, in which a cooling fluid continuously circulates to maintain a constant temperature. A copper heating block $(4 \mathrm{~cm} \times 4 \mathrm{~cm} \times 1 \mathrm{~cm})$ is located above the cooling block. Two resistance heaters $(100 \mathrm{~W}$ and $120 \mathrm{~V}$ ) are placed in the middle of the heating block to increase its temperature to control the temperature of the sample holder. The temperature of the heating block is regulated by a temperature controller via a thermocouple. A sample holder $(4 \mathrm{~cm} \times 2 \mathrm{~cm} \times 1 \mathrm{~cm})$ made of stainless steel is placed on top of the heating block. To ensure good thermal contact between the sample holder, the heating block, and the cold block, the three are attached by screws on each corner. The sample holder is divided in two parts (i.e., top and bottom; Fig. S1c) with a Teflon spacer between them. Aerosol samples collected on the glass coverslips (Fig. 2a) are placed between the two sections of the sample holder. Afterwards, these sections are fixed in place with four screws. As shown in Fig. S1b, a circular glass window is placed on the top of the sample holder to avoid any interference of the ambient air. An optical microscope (Axiolab Zeiss, Germany) with a $5 \times / 0.12$ magnification objective is coupled with the sample holder (Fig. 3).

To maintain the temperature of the cooling block at ca. $-80^{\circ} \mathrm{C}$, polydimethylsiloxane circulates through it with the help of a pump inside the cooling bath (PRO-RP1090, LAUDA). A humid/dry air system is required to form liquid droplets on the aerosol particles deposited on the glass coverslips. While humid air is obtained when the nitrogen (grade 4.8, INFRA) passes through a bubbler filled with pure water (LAL reagent water, Associates of Cape Cod, Inc.), dry conditions are experienced when nitrogen is injected and flows towards the sample. The air is directed by stainless steel tubes (Swagelok), and the flows are controlled by four Swagelok valves (Fig. 3). Each experiment is recorded by a video camera (MC500-W, JVLAB) attached to the microscope, and the video images are used for further analysis. The temperature at the center of the sample holder was obtained with a resistance temperature detector (RTD) with a precision of $0.1^{\circ} \mathrm{C}$ and an uncertainty of 0.1 to $0.56^{\circ} \mathrm{C}$ between 0 and $-40^{\circ} \mathrm{C}$, respectively. The RTD is connected to a FieldLogger device (RS485, NOVUS) to acquire the data (Fig. 3).

The aim of the UNAM-DFT is to mimic ice particle formation via immersion freezing; hence, a full experiment is performed as follows. At room temperature, the coverslip containing the aerosol particles is placed on the cold stage. The sample holder is isolated from the ambient atmosphere by tightening the screws and positioning the circular glass window on top of the heating block when the temperature is at $0{ }^{\circ} \mathrm{C}$ (Fig. 2b). Humid air is directed towards the sample holder to induce liquid droplet formation by water vapor condensation, as shown in Fig. 2c. Once the droplets have reached a diameter of $170 \mu \mathrm{m}$ (on average), dry air is directed toward the sample holder to shrink the droplets and minimize the contact between them (Fig. 2d). Approximately 30-40 droplets are formed on each glass coverslip. Afterwards, the humid/dry air system is closed, and the sample holder is completely isolated by closing the valves. Finally, the temperature of the sample holder is decreased from 0 to $-40^{\circ} \mathrm{C}$ at a cooling rate of $10^{\circ} \mathrm{C} \mathrm{min}^{-1}$. During the temperature ramp, the droplets freeze, promoted by the aerosol particles immersed within the droplets (Fig. 2e); otherwise, they are expected to freeze homogeneously close to $-38^{\circ} \mathrm{C}$.

\section{Frozen fraction}

The temperatures from the sample holder and the images in the videos are analyzed to determine the freezing temperature of each droplet. The first metric employed was the frozen fraction $\left(F_{\text {ice }}\right)$ :

$F_{\text {ice }}=\frac{N_{\text {ice }}}{N_{\text {ice }}+N_{\text {droplets }}}$, 
(a)

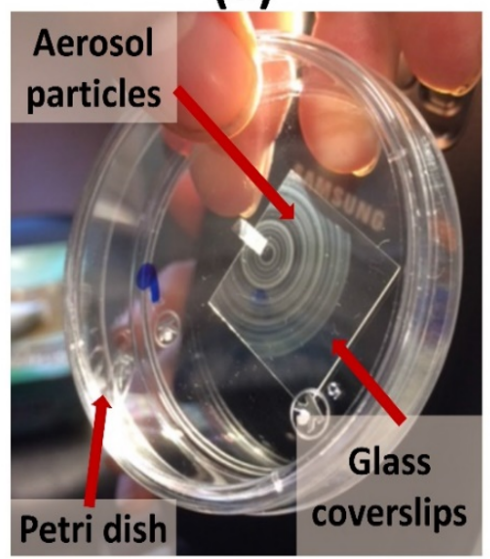

(b)

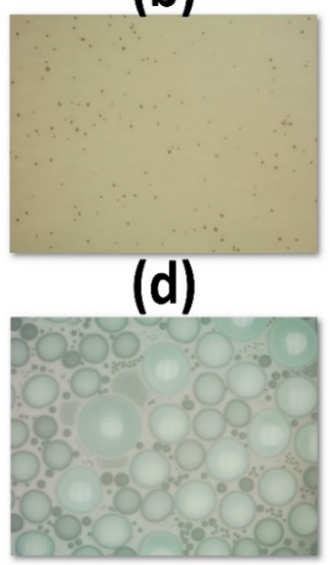

(c)
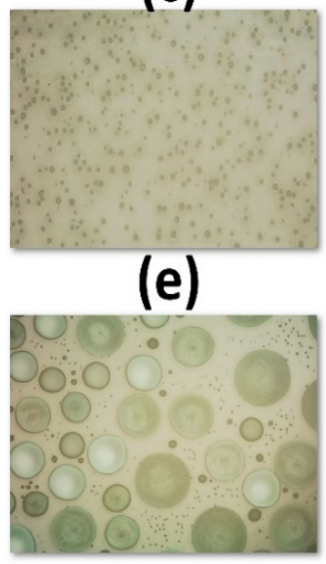

Figure 2. (a) Aerosol particles collected on a hydrophobic glass coverslip, (b) aerosol particles seen from the microscope $(d=5.6-10 \mu m)$, (c) water vapor condensation on the aerosol particles, (d) liquid droplets, and (e) frozen (opaque colors) and unfrozen droplets as seen by the optical microscope.

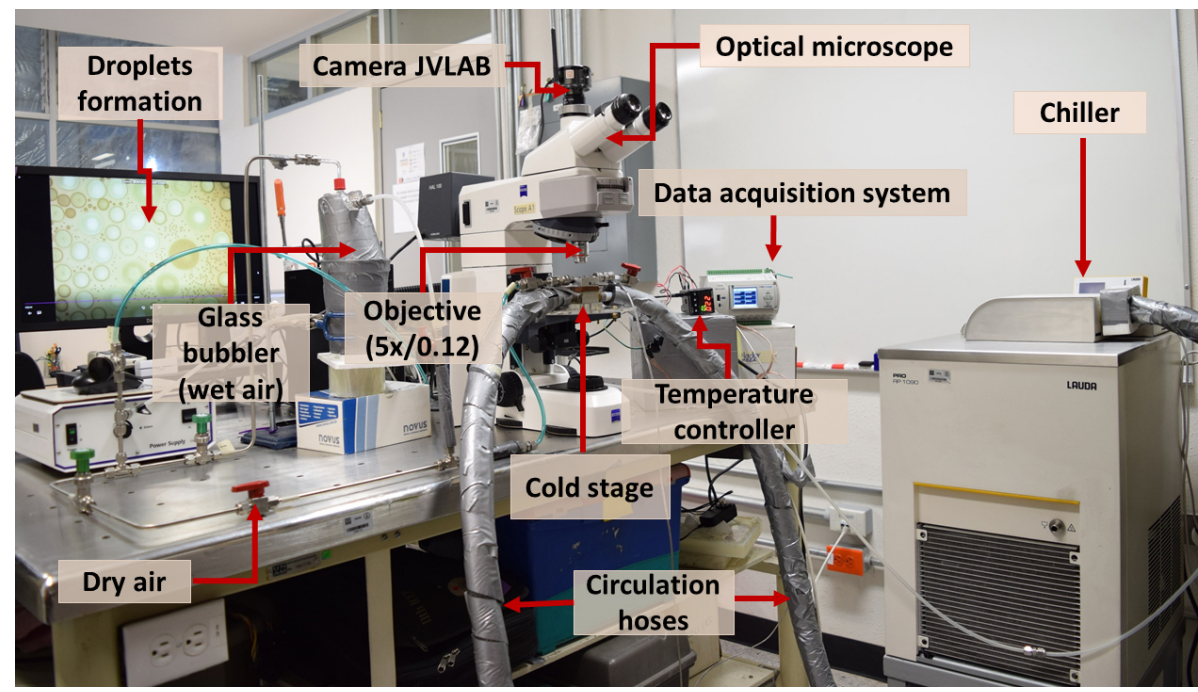

Figure 3. UNAM-DFT experimental setup with its main components. Figure S1 shows a zoom of the cold stage.

where $N_{\text {ice }}$ is the number of frozen drops (dimensionless) and $N_{\text {droplets }}$ is the number of unfrozen droplets (dimensionless) (Kanji et al., 2017).

\section{INP concentration}

The INP number concentration $\left(\mathrm{L}^{-1}\right)$ was calculated using the following expression (Mason et al., 2015a):

$$
\begin{aligned}
{[\operatorname{INP}(T)] } & =-\ln \left(\frac{N_{u}(T)}{N_{o}}\right) \cdot\left(\frac{A_{\text {deposit }}}{A_{\mathrm{DFT}} V}\right) \cdot N_{o} \cdot f_{\mathrm{ne}} \\
& \cdot f_{\mathrm{nu}, 0.25-0.10 \mathrm{~mm}} \cdot f_{\mathrm{nu}, 1 \mathrm{~mm}},
\end{aligned}
$$

where $N_{\mathrm{u}}(T)$ is the number of unfrozen droplets at a temperature $T\left({ }^{\circ} \mathrm{C}\right), N_{0}$ is the total number of droplets (dimen- sionless), $A_{\text {deposit }}$ is the total area of the aerosol particles deposited on the MOUDI hydrophobic glass cover slip $\left(\mathrm{cm}^{2}\right)$, $A_{\text {DFT }}$ is the area of the sample analyzed by the DFT $\left(\mathrm{cm}^{2}\right), V$ is the volume of air through the MOUDI (L), $f_{\text {ne }}$ is a correction factor to account for the uncertainty associated with the number of nucleation events in each experiment (dimensionless), and $f_{\text {nu }}$ is a correction factor to account for changes in particle concentration across each MOUDI sample (dimensionless).

Equation (2) considers the possibility that multiple particles can be present within a droplet (Vali, 1971). As part of the data analysis, two corrections are included. The first is related to the total area covered by the particles deposited on the coverslips, which varies between $425 \mathrm{~mm}^{2}$ and $605 \mathrm{~mm}^{2}$ as a function of the MOUDI stage. The second is related to 
inhomogeneities in particle deposit. The correction factor associated with the nucleation events $\left(f_{\text {ne }}\right)$ was calculated with a $95 \%$ confidence level (Mason et al., 2015a). More details on these corrections can be found in Mason et al. (2015a).

\subsubsection{Surface active site density $\left(n_{\mathrm{s}}\right)$}

The $n_{\mathrm{S}}$ values were derived at $-15,-20,-25$, and $-30^{\circ} \mathrm{C}$ using Eq. (3):

$n_{\mathrm{S}}(T)=\frac{[\mathrm{INP}(T)]}{S_{\mathrm{tot}}}$

where $[\operatorname{INP}(T)]$ is the INP concentration at temperature $T$ and $S_{\text {tot }}$ is the total surface area of all aerosol particles. See the Supplement for more details on how $S_{\text {tot }}$ was calculated.

\subsubsection{Aerosol number and mass concentration}

The particle size distributions for equivalent optical diameters (EODs) between 0.3 and $25 \mu \mathrm{m}$ were obtained with optical particle counters, a PMS LasAir II 310A (0.3 to $25 \mu \mathrm{m})$ and PMS LasAir III 310C (0.3 to $10 \mu \mathrm{m})$, as listed in Table 1, operated at a flow rate of $28.3 \mathrm{~L} \mathrm{~min}^{-1}$ and at a sampling rate of $11 \mathrm{~Hz}$. The particle mass concentrations, i.e., $\mathrm{PM}_{10}$ and $\mathrm{PM}_{2.5}$, were obtained with a FH62C14 Thermo Scientific Inc., operated at a flow rate of $16.7 \mathrm{~L} \mathrm{~min}^{-1}$.

\subsubsection{Chemical composition}

For the chemical analysis, aerosol particles were collected on $47 \mathrm{~mm}$ Teflon filters (Pall Science) for $48 \mathrm{~h}$ in Mérida in 2017 and 2018 and in Sisal in 2017. A 24h sample was also made in Sisal in 2018. Note that there were two different sampling periods in Sisal to evaluate the interannual variability in aerosol loading. The aerosol particles were collected using a MiniVol (TAS, Airmetrics), a Partisol (2025i, Thermo Fisher Scientific), and a cascade impactor (MOUDI 100NR, MSP) (see Table 1).

The Teflon filters were analyzed by X-ray fluorescence (XRF) to determine the elemental composition with an Xray spectrometer at the Laboratorio de Aerosoles, Instituto de Física, UNAM (Espinosa et al., 2012). The spectrometer uses an Oxford Instruments (Scotts Valley, CA, USA) X-ray tube with an Rh anode and an Amptek X-123SDD spectrometer (Bedford, MA, USA) operated at $50 \mathrm{kV}$ and a current of $500 \mu \mathrm{A}$, irradiating during $900 \mathrm{~s}$ per spectrum. A set of thin film standards (MicroMatter Co., Vancouver, Canada) was used for the calibration of the instrument. The spectra were analyzed using the AXIL (QXAS) software. The chemical composition was quantified using the methodology reported by Espinosa et al. (2010). Once the concentration of each analyzed element was obtained, the fraction (in percentage) with respect to the total mass concentration was derived.

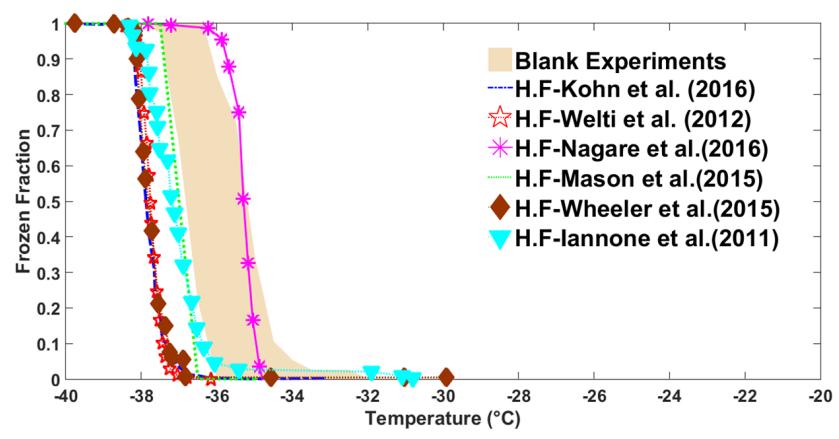

Figure 4. Activation curve for the blank experiments (rose shaded area) obtained with the UNAM-DFT using pure water. Colored lines correspond to homogeneous freezing (H.F.) curve literature data. Dashed blue line: Kohn et al. (2016); red stars: Welti et al. (2012); magenta asterisks: Nagare et al. (2016); dotted green line: Mason et al. (2015a); brown diamonds: Wheeler et al. (2015); and cyan triangles: Iannone et al. (2011).

\subsubsection{Meteorological variables}

Wind speed, wind direction, air temperature, and RH were obtained using meteorological stations. During Sisal 2017, a Davis (Vantage Pro2) meteorological station located $20 \mathrm{~m}$ away from the other instruments was used. Meteorological data during the four other sampling periods were obtained from meteorological sensors from the University Network of Atmospheric Observatories (RUOA), which were installed at SC-UADY and EI-UNAM. Additionally, back trajectories of the air masses arriving in Mérida and Sisal were estimated with the Hybrid Single-Particle Lagrangian Integrated Trajectory (HYSPLIT) model from the National Oceanic and Atmospheric Administration (NOAA) over $24 \mathrm{~h}$ and $13 \mathrm{~d}$. The $24 \mathrm{~h}$ back trajectories were run for the BB events as they were likely locally emitted. On the other hand, the back trajectories for the cold fronts (MA) and African dust intrusions (AD) were run for $13 \mathrm{~d}$ as the particles carried by those events take several days to reach Mexico.

\section{Results and discussion}

\subsection{UNAM-DFT performance}

The sensitivity response of the UNAM-DFT was evaluated using blank experiments with pure water (LAL Reagent Water, Associates of Cape Cod, Inc.). In this case, new glass coverslips were placed on the sample holder, and droplets ( $d=126 \mu \mathrm{m}$ on average) were formed on them by the condensation of water vapor on the substrate surface. The freezing temperature of each droplet was later determined.

Figure 4 shows that most of the droplets (i.e., $95 \%$ ) froze homogeneously, i.e., with no particles in them and at temperatures below $-36^{\circ} \mathrm{C}$ (rose shaded area). The freezing temperatures of the blank experiments are in agreement with 
previous homogeneous freezing values reported for liquid droplets using different methods (Welti et al., 2012; Kohn et al., 2016; Nagare et al., 2016). This indicates that the substrate does not impact the heterogeneous freezing results discussed below. The small differences between our results and published homogeneous freezing curves can be attributed to differences in the droplet's size, the purity of the water, the exposure time of the droplets to low temperatures, and the freezing technique. For example, Kohn et al. (2016) used the Portable Immersion Mode Cooling chAmber (PIMCA) coupled with the Portable Ice Nucleation Chamber (PINC) with droplet sizes ranging from 10 to $14 \mu \mathrm{m}$ in diameter (dashed blue line). Welti et al. (2012) (red stars) and Nagare et al. (2016) (magenta asterisks) used the Immersion Mode Cooling chAmber - Zurich Ice Nucleation Chamber (IMCAZINC) with $\approx 20 \mu \mathrm{m}$ droplets in diameter. Note that droplet sizes obtained with the UNAM-DFT are much larger than those used in the aforementioned studies. Additionally, the homogeneous freezing experiments in the UNAM-DFT take around $4 \mathrm{~min}$ in contrast with the residence time of droplets in the PIMCA-PINC and the IMCA-ZINC which are less than 10 s. Iannone et al. (2011) and Wheeler et al. (2015) also performed homogeneous freezing experiments using a DFT. Both studies found that $90 \%$ of the droplets froze at $-37^{\circ} \mathrm{C}$ (brown diamonds and cyan triangles, respectively). Although the total times of the experiments between the present study and those performed by Iannone et al. (2011) and Wheeler et al. (2015) are comparable, the size of the droplets may be slightly different.

Additionally, as shown by Lacher et al. (2021), INP concentrations reported by the UNAM-DFT during the Puy de Dôme Ice Nucleating Intercomparison Campaign (PICNIC) are in good agreement with the values reported by other online and offline techniques, such as the Portable Ice Nucleation Experiment (PINE) instrument, the Ice Nucleation Spectrometer of the Karlsruhe Institute of Technology (INSEKT), the FRankfurt Ice Deposition freezinG Experiment (FRIDGE), the Colorado State University Ice Spectrometer (IS), the Ice Nucleation Droplet Array (INDA), the Leipzig Ice Nucleation Array (LINA), and the LED-based Ice Nucleation Detection Apparatus (LINDA). The results in Lacher et al. (2021) indicate that the UNAM-MOUDI-DFT is very robust with a high level of confidence.

\subsection{Chemical composition vs. air mass}

To corroborate if the aerosol particles collected in January, April, and July in the Yucatán Peninsula were influenced by MA, BB, and $\mathrm{AD}$ air masses, respectively, the elemental chemical composition obtained by XRF was evaluated, as shown in Fig. 5. The pie charts show the composition of particles under background conditions for Mérida (a) and Sisal (b). For Mérida, the background corresponds to those particles collected on days with $\mathrm{PM}_{10}$ levels below the 10th percentile in the absence of $\mathrm{BB}$ and $\mathrm{AD}$. For Sisal, the back- ground corresponds to those particles collected in January in the absence of BB and AD. Although Mérida and Sisal are rather close (ca. $49 \mathrm{~km})$, the elemental composition in both sites differs with the former likely influenced by urban emissions and the later by MA. $\mathrm{Na}$ and $\mathrm{Cl}$ are ubiquitous in Mérida and Sisal due to their proximity to the GoM. Since karstic sediments form the soil in Yucatán, the presence of $\mathrm{Ca}$ is expected as well.

Given that Sisal is a remote coastal Village with almost no industrial activities, the background aerosol composition measured in January can be considered as representative of the MA composition for the Yucatán Peninsula as the presence of $\mathrm{BB}$ and $\mathrm{AD}$ particles is very low. Figure 5b indicates that chlorine, sodium, sulfur, calcium, potassium, and magnesium were the most abundant elements influenced by MA. The presence of these elements agrees with results reported in studies focused on MA (Parungo et al., 1986; Xia and Gao, 2010; Prather et al., 2013). Prather et al. (2013) classified MA particles in four categories: inorganic sea salts (SSs) mainly composed of $\mathrm{NaCl}$, inorganic sea salt plus organic carbon (SS-OC), biological particles, and organic particles (OCs) in which organic species can be coupled with ions such as sulfur, magnesium, and calcium. O'Dowd et al. (2004), Ovadnevaite et al. (2014), and Lee et al. (2015) reported that the fraction of SSs in the marine aerosol was $74 \%, 14 \%-85 \%$, and $72 \%$, respectively. Furthermore, the high percentage of sulfur is associated with dimethyl sulfide (DMS) emissions related to the marine biological activity linked to phytoplankton blooms (Yoch, 2002; Barnes et al., 2006). Herrera-Silveira et al. (2004a) characterized the phytoplankton in the GoM between 1999 and 2002, finding that diatoms, dinoflagellates, and chlorophytes are the most abundant types of phytoplankton on the coast of Sisal. Therefore, these microorganisms could contribute to the sulfur emissions in this zone.

Besides $\mathrm{Na}$ and $\mathrm{Cl}$, sulfur is the most abundant element observed in the background aerosol particles in Mérida (Fig. 5a). The presence of sulfur can be attributed to anthropogenic sources, such as light- and heavy-duty vehicles with diesel engines that are prevalent in Mérida. Given the proximity of Mérida to the GoM, part of the sulfur measured in Mérida could originate from DMS. To assess the influence of the likely BB and AD particles collected in April and July in Mérida, respectively, the enrichment factor (against the background composition) was calculated for each of the 16 analyzed elements (Fig. 5c). Sulfur, potassium, aluminum, nickel, and iron were found to have an enrichment factor above 1.0 under the influence of BB (red bars). Higher concentrations of $\mathrm{S}$ and $\mathrm{K}$ were found in Mérida during the $\mathrm{BB}$ season, in agreement with Reid et al. (2005) who reported that particles emitted during BB could contain trace inorganic species (e.g., sulfates, nitrate, chlorine, calcium, and potassium). Potassium, a key element emitted during BB, is an important nutrient for the plants and is absorbed in the woody material through their roots (Jones et al., 2007). 

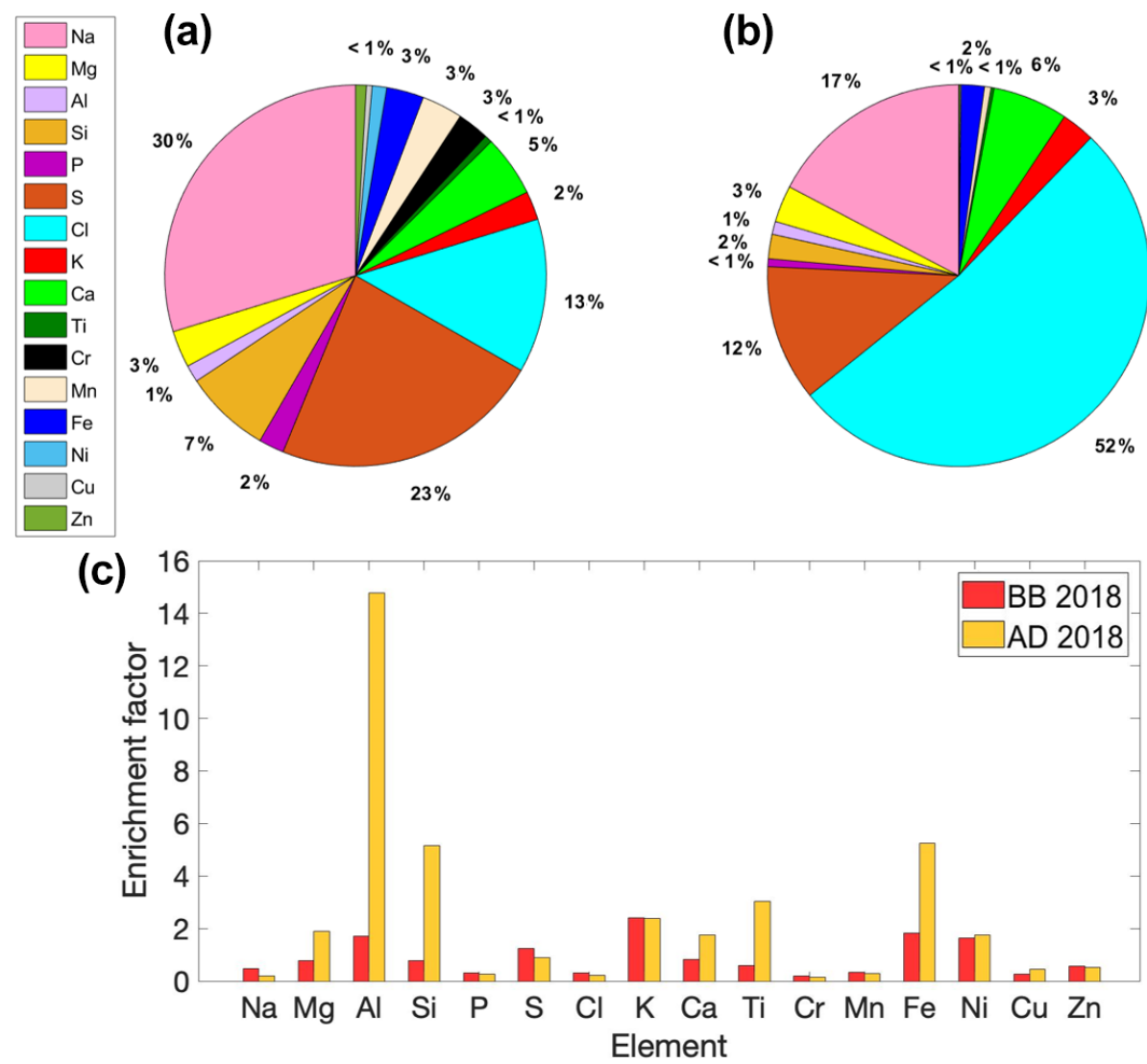

Figure 5. Percentage of elemental mass concentrations for background samples in Mérida (a) and Sisal (b). Enrichment factors are calculated for samples obtained under the influence of BB (red bars) and AD (yellow bars) plumes from background conditions in Mérida (c).

Moreover, the mass concentration of $\mathrm{PM}_{2.5}$ positively correlated with K (>0.6) (Fig. S2a), corroborating that the sampled air masses during this season contained a comparatively high mass fraction of particles emitted from $\mathrm{BB}$ when $\mathrm{PM}_{2.5}$ was high. Note that $\mathrm{Li}$ et al. (2003) found that soot aggregates emitted by $\mathrm{BB}$ may contain potassium salts $\left(\mathrm{K}_{2} \mathrm{SO}_{4}\right.$, $\mathrm{KNO}_{3}$, and $\mathrm{KCl}$ ) and, in minor quantity, elements such as iron, calcium, and magnesium.

Figure $5 \mathrm{c}$ shows the significant enrichment of elements such as silicon, aluminum, and iron, which are characteristic of mineral dust particles, during the AD period (yellow bars). Additionally, positive correlation coefficients $(\geq 0.8)$ between the mass concentrations of $\mathrm{PM}_{2.5}$ and $\mathrm{Mg}, \mathrm{Al}, \mathrm{Si}$, $\mathrm{K}, \mathrm{Ti}$, and Fe were found (Fig. S2b). Rosinski et al. (1988) reported high percentages of these elements in aerosol particles collected during July and August in 1986 over the GoM. The authors attributed this composition to air masses originating in the east (probably from Africa). The elements Al, $\mathrm{Si}, \mathrm{Ca}$, and $\mathrm{Fe}$ are typically found in mineral dust particles (Linke et al., 2006; Querol et al., 2019).

Figure S2c shows the total organic carbon concentration (TOC) for the $\mathrm{BB}$ and $\mathrm{AD}$ periods, providing further evidence that the two air masses were completely different, with higher TOC concentrations (by $2.0 \mu \mathrm{g} \mathrm{m}^{-3}$ ) observed during the BB period.

Overall, important differences in elemental composition are evident in the aerosol particles collected in January, April, and July in the Yucatán Peninsula, corroborating the presence of MA, BB, and AD particles as suggested by previous studies (e.g., Yokelson et al., 2009; Kishcha et al., 2014; Ríos and Raga, 2018; Ladino et al., 2019; Raga et al., 2021; TrujanoJiménez et al., 2021; Ramírez-Romero et al., 2021).

\subsubsection{Aerosol size distribution vs. air mass}

Figure 6 shows the average aerosol size distributions sampled under the influence of the different air masses: MA (cyan), $\mathrm{BB}$ (red), and $\mathrm{AD}$ (yellow). For all three air masses, the highest particle concentration (reported by the LasAir) was observed for particles with EODs between 0.3 and $0.5 \mu \mathrm{m}$. For particles larger than $0.5 \mu \mathrm{m}$, the concentration decreases with size. Out of the three air masses, AD reported the highest particle concentration for particles ranging from 0.3 to $5.0 \mu \mathrm{m}$. Likewise, the highest particle concentration for particles between 5.0 and $25 \mu \mathrm{m}$ was found in the MA air masses. Except for the smallest size bin (i.e., $0.3-0.5 \mu \mathrm{m}$ ), aerosol particles 


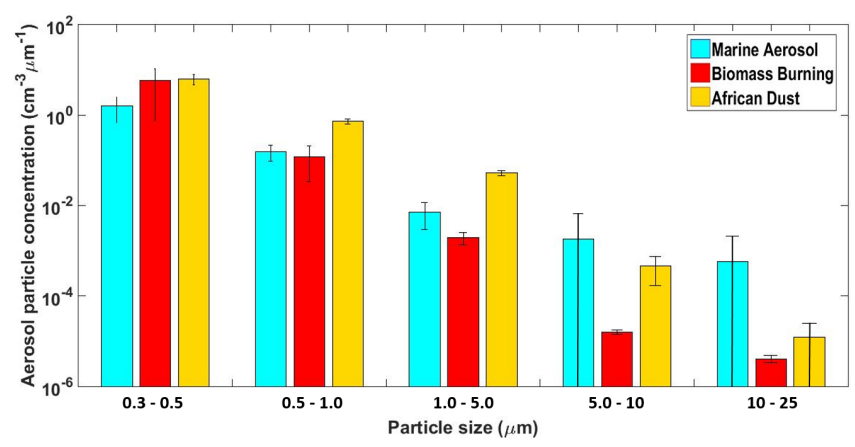

Figure 6. Average aerosol size distribution derived from the optical particle counters for the three air masses: MA (cyan bars), AD (yellow bars), and BB (red bars). The error bars represent the standard deviation.

measured during the BB season showed the lowest concentration in comparison to the other two air masses.

The size distribution for MA measured in Sisal is comparable to those reported by $\mathrm{Si}$ et al. (2018) for three different marine sites with lower concentrations (North Pacific, North Atlantic, and Arctic oceans). Generally, the coast of Sisal is very calm with moderate wave activity; however, during the MA sampling period, two cold fronts impacted the Yucatán Peninsula, increasing the wind speed up to $28 \mathrm{~km} \mathrm{~h}^{-1}$. High wind speeds generate breaking waves that produce sea spray particles by bubble bursting. Figure S3a shows examples of back trajectories obtained with HYSPLIT during the presence of one of the cold fronts, indicating that air masses crossed the GoM prior to their arrival in Sisal.

The AD particle number concentration measured in Sisal was found to be lower compared with data published from other studies. For example, Gong et al. (2020b) reported that the aerosol concentrations measured on São Vicente island, Cape Verde, under the influence of $\mathrm{AD}$ for particles larger than $1.0 \mu \mathrm{m}$ varied between 3 and $71 \mathrm{~cm}^{-3}$. Kaaden et al. (2009) found that under the influence of Saharan dust particles in Morocco, the mean aerosol concentration for particles larger than $1.0 \mu \mathrm{m}$ was $70 \mathrm{~cm}^{-3}$. The lower particle number concentration measured in the Yucatán Peninsula is attributed to the long distance the AD particles traveled before arriving at Mexico. While crossing the Atlantic, many particles can be removed from the atmosphere by dry deposition and, to a lesser extent, by wet deposition as cloud formation is low during this season.

Although coarse particles were measured during the BB season at a much lower concentration, those particles may likely be associated with background particles such as resuspended dust. Field studies of BB emissions have mostly focused on submicron particles (e.g., Pósfai et al., 2003; Zhang et al., 2011). Guyon et al. (2005) found that during BB events in the Amazonia, the maximum submicron particle concentration was around $100 \mathrm{~cm}^{-3}$ in fresh and detrained smoke.

\subsection{INP concentration vs. air mass}

The INP concentration as a function of temperature and air mass type for particles between 0.32 and $10 \mu \mathrm{m}$ is shown in Fig. 7a. Samples obtained under the influence of MA produced particles that froze at the warmest temperatures of the three different air masses with onset freezing temperatures as high as $-5^{\circ} \mathrm{C}$. The $\mathrm{AD}$ particles were able to activate ice particle formation at temperatures below $-9{ }^{\circ} \mathrm{C}$. BB particles were the least efficient with onset freezing temperatures colder than $-19^{\circ} \mathrm{C}$.

The INP concentrations for MA (cyan circles) were found to range from 0.068 to $18.90 \mathrm{~L}^{-1}$ at temperatures between -5 and $-31^{\circ} \mathrm{C}$. The present results were found to be higher than those reported by Mason et al. (2016) for the west coast of Canada when the air masses were coming from the northwest (i.e., 0.10 to $6.1 \mathrm{~L}^{-1}$ at temperatures from -15 to $-25^{\circ} \mathrm{C}$ ), by Si et al. (2018) and Irish et al. (2019) in the Arctic $\left(0.004\right.$ to $0.67 \mathrm{~L}^{-1}$ at temperature ranging from -15 to $\left.-25^{\circ} \mathrm{C}\right)$, by Mason et al. (2016) in Alert $\left(0.05\right.$ to $0.99 \mathrm{~L}^{-1}$ at temperatures from -15 to $\left.-25^{\circ} \mathrm{C}\right)$, and by DeMott et al. (2016) in Puerto Rico $\left(0.0002\right.$ to $0.02 \mathrm{~L}^{-1}$ at temperatures from -6 to $-24{ }^{\circ} \mathrm{C}$ ). However, the present results are similar to those reported by Mason et al. (2016) on the east coast of Canada for southeastern air masses $\left(0.38\right.$ to $2.8 \mathrm{~L}^{-1}$ at temperatures from -15 to $\left.-25^{\circ} \mathrm{C}\right)$. Recall that the MA samples in Sisal were collected during the winter and in the presence of cold fronts. Therefore, the high wind speeds associated with the cold fronts, and hence wave breaking, could have played an important role in the high INP concentrations measured in Sisal, as discussed in Ladino et al. (2019). Additionally, given that air temperatures, RH, and sea surface temperatures are considerably different between the tropics and higher latitudes, these differences could be partially responsible for the latitudinal differences observed in INP concentrations.

The aerosol particles collected during the AD period produced the highest INP concentrations with values ranging between 0.071 and $36.07 \mathrm{~L}^{-1}$ at temperatures from -9 to $-29^{\circ} \mathrm{C}$ (yellow squares). As shown in Fig. 5, the AD particles were enriched in $\mathrm{Al}, \mathrm{Fe}$, and $\mathrm{Si}$, which are present in different minerals and clays (Querol et al., 2019). Although 2018 was a more active AD season than 2017, as characterized by higher $\mathrm{PM}_{2.5}$ and $\mathrm{PM}_{10}$ concentrations (Ramírez-Romero et al., 2021), the INP concentrations measured in 2018 in the Yucatán Peninsula were lower than values reported elsewhere. For example, Ardon-Dryer and Levin (2014) found that the INP concentrations in the eastern Mediterranean ranged between 0.16 and $234 \mathrm{~L}^{-1}$ at temperatures between -11.8 and $-28.9^{\circ} \mathrm{C}$, and larger values (up to $10^{3} \mathrm{~L}^{-1}$ ) at temperatures from -18 to $-29^{\circ} \mathrm{C}$ were reported by Reicher et al. (2019). Price et al. (2018) found that in Cape Verde, the INP concentrations were an order of magnitude higher $\left(0.1\right.$ and $10^{2} \mathrm{~L}^{-1}$ at temperatures from about -10 to $-25^{\circ} \mathrm{C}$ ) than those measured in Sisal and Mérida. Note 

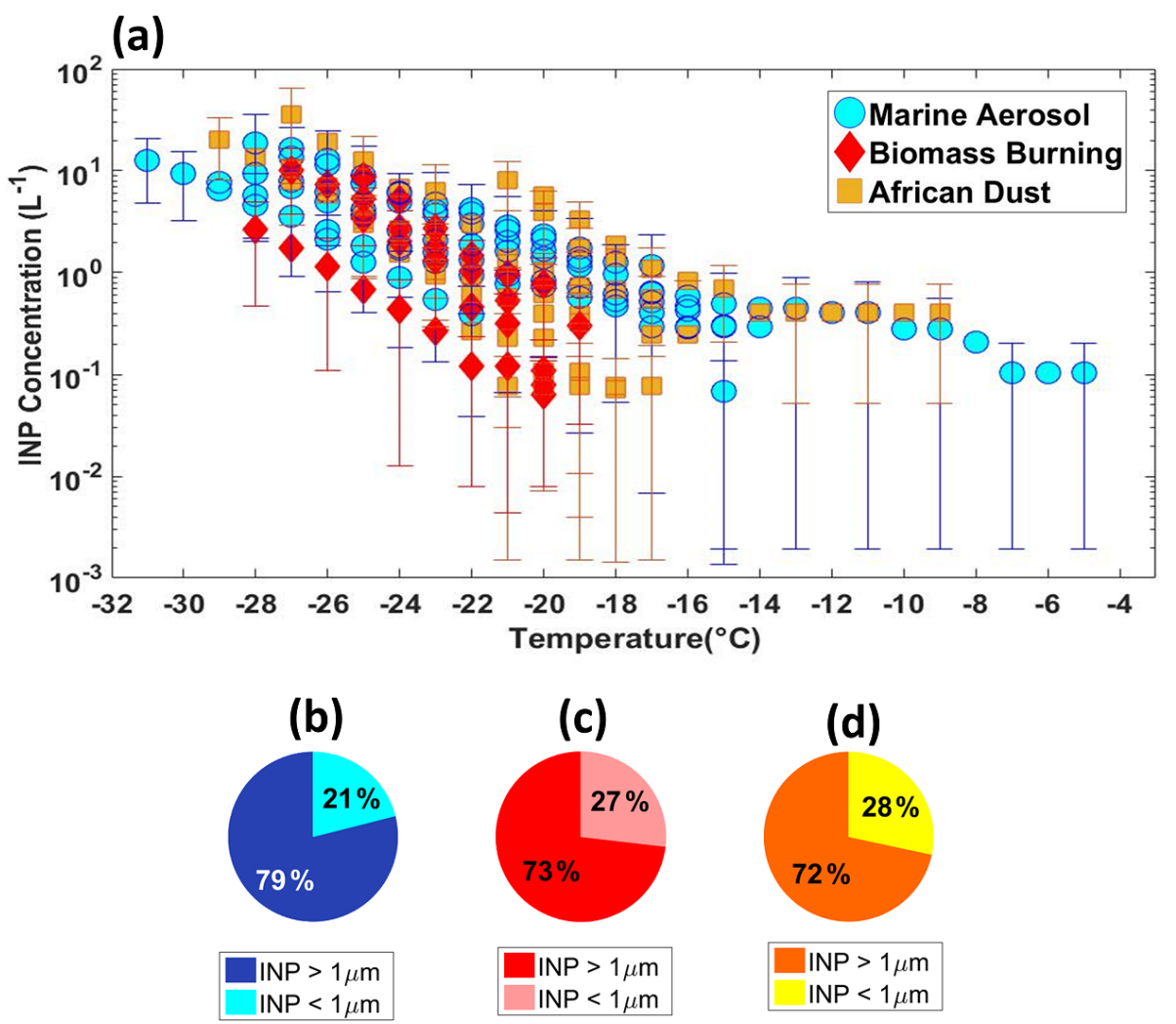

Figure 7. (a) INP concentrations as a function of temperature for MA (cyan circles), AD (yellow squares), and BB (red diamonds) for aerosol particles with sizes ranging between 0.32 and $10 \mu \mathrm{m}$. The pie charts illustrate the contribution of supermicron and submicron particles to the total INP concentrations for (b) MA, (c) BB, and (d) AD.

that the measurements reported by Ardon-Dryer and Levin (2014), Price et al. (2018), and Reicher et al. (2019) were performed relatively close to the mineral dust source, i.e., the Sahara and Arabian deserts. The lower values measured in the Yucatán Peninsula during the AD period can be associated with the long distance $(>8000 \mathrm{~km})$ that the mineral dust particles traveled before reaching Mexico. During the long-range transport, the physicochemical properties of the AD particles may experience chemical aging, likely impacting their ice nucleating abilities, which is consistent with the results of Boose et al. (2016). Also, those particles may have been exposed to different dilution and removal processes during long-range transport, likely reducing the concentration of INPs.

The measured INP concentration during the BB period was found to range between 0.063 and $10.21 \mathrm{~L}^{-1}$ at temperatures from -19 to $-28^{\circ} \mathrm{C}$ (red diamonds), the lowest INP concentrations, on average, of the three aerosol types. BB particles have been reported as inefficient INPs via immersion freezing with a higher potential to catalyze ice particles at temperatures below $-40^{\circ} \mathrm{C}$ via deposition nucleation (Kanji et al., 2017). The concentrations of INPs measured in Mérida during the BB periods are lower than those reported by Prenni et al. (2012), McCluskey et al. (2014), and
Levin et al. (2016). The lower concentrations reported in the present study can be attributed to the long distance between the burning areas (likely southern Mexico and Central America) and the sampling site. Additionally, it has been shown that the type of fuel or biomass can determine the ice nucleating abilities of the BB emitted particles. McCluskey et al. (2014) found clear differences in the ice nucleating abilities of different prescribed burns and wildfires.

Given that the UNAM-MOUDI-DFT can differentiate between the INP concentrations as a function of the aerosol aerodynamic size, the contributions of the submicron and supermicron particles to the total INP concentrations were assessed for the three aerosol types. Figure $7 b$ to $d$ shows that supermicron particles are the major contributor $(>72 \%)$ to the INP concentrations for all aerosol types. Note that this contribution is largest for the MA. These results are in agreement with previous studies (e.g., Mason et al., 2015b, 2016; Ladino et al., 2019; Gong et al., 2020a). The current results and the aforementioned studies highlight the importance of supermicron particles in ice cloud formation.

\subsection{Surface active site density}

Figure 8 summarizes the $n_{\mathrm{s}}$ values calculated for the three periods, i.e., MA, BB, and AD. As shown in Fig. S4, the $n_{\mathrm{S}}$ 


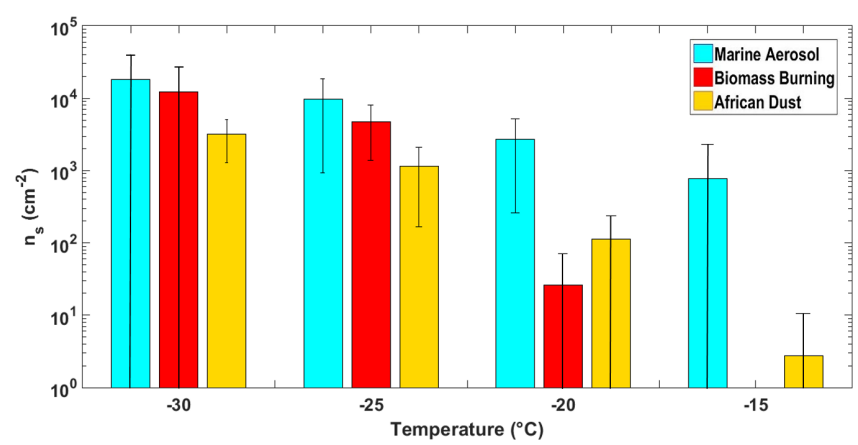

Figure 8. Surface active site density $\left(n_{\mathrm{S}}\right)$ as a function of temperature for $\mathrm{MA}, \mathrm{BB}$, and $\mathrm{AD}$ particles. The error bars represent the standard deviation.

values reported in the literature for $\mathrm{MA}, \mathrm{BB}$, and $\mathrm{AD}$ cover several orders of magnitude. The $n_{\mathrm{S}}$ obtained for the MA and BB particles overlap with the published range of $n_{\mathrm{s}}$ values. The MA and $\mathrm{BB} n_{\mathrm{s}}$ values were found to agree with those reported by DeMott et al. (2016) and Umo et al. (2015), respectively. At -15 and $-20^{\circ} \mathrm{C}$, the $n_{\mathrm{s}}$ values for the AD period were found to agree with the values reported by Gong et al. (2020a). However, in comparison to the literature, lower $n_{\mathrm{s}}$ values were found for the $\mathrm{AD}$ period at temperatures below $-20^{\circ} \mathrm{C}$. Note that some of the $n_{\mathrm{s}}$ data in the comparison refer to pure components or aerosol types, while our analysis includes the entire atmospheric aerosol variability, i.e., also the surface of particles not acting as ice nucleating particles.

Although the $\mathrm{AD}$ particles had the highest INP concentrations between -9 and $-29^{\circ} \mathrm{C}$ (Fig. 7), Figure 8 shows that the MA had the highest $n_{\mathrm{s}}$ values in the Yucatán Peninsula (at least in winter), followed by $\mathrm{AD}$ at temperatures above $-25^{\circ} \mathrm{C}$. On the other hand, BB particles had lower $n_{\mathrm{s}}$ values at -20 and $-15^{\circ} \mathrm{C}$ but comparable values to the other air masses at -25 and $-30^{\circ} \mathrm{C}$.

Given that AD particles traveled $>8000 \mathrm{~km}$ before reaching the Yucatán Peninsula, the low $n_{\mathrm{s}}$ values calculated for the $\mathrm{AD}$ particles are not unexpected. It is likely that the most efficient INPs could have been washed out while traveling over the Atlantic. Also, it is well known that aerosol aging can strongly affect the ice nucleating abilities of mineral dust particles (Kanji et al., 2017). Therefore, the composition of the AD particles that arrived at the Yucatán Peninsula may significantly differ from the AD particles found closer to their source with different ice nucleation efficiencies.

Large $n_{\mathrm{s}}$ values can be likely associated with the presence of biological particles, as was the case in Si et al. (2018) which linked the high $n_{\mathrm{S}}$ values with the presence of terrestrial biological particles. However, McCluskey et al. (2018) and DeMott et al. (2016) showed that these kind of particles can also be of marine origin as there is large biological activity in marine environments. Rodriguez-Gomez et al. (2020) showed different terrestrial and marine microorganisms that were identified in Sisal which can be linked with the high $n_{\mathrm{s}}$ values found for the MA samples.

\section{Conclusions}

The UNAM-MOUDI-DFT apparatus was successfully built at the Universidad Nacional Autónoma de México. This new device can be used to study ice formation via immersion freezing and can discriminate the INP concentrations as a function of the aerosol aerodynamic size from $0.32 \mu \mathrm{m}$ to $10 \mu \mathrm{m}$. The performance of the UNAM-MOUDI-DFT was assessed by conducting homogeneous freezing experiments with pure water and evaluated against other online and offline cloud chambers during the Puy de Dôme Ice Nucleating Intercomparison Campaign (PICNIC), which is discussed in a separate publication. The overall performance of the new device was found to be very good, providing high-quality results. The UNAM-MOUDI-DFT is expected to help the scientific community understand the main sources of INPs at tropical latitudes and to provide information urgently needed for the development of new ice nucleation parameterizations that include aerosol particles emitted in the tropics.

Aerosol particles originating from three different sources (marine aerosol, biomass burning, and African dust) were collected between January 2017 and July 2018 in Sisal and Mérida, Yucatán (Mexico). The three different aerosol types were characterized by their physicochemical properties (i.e., elemental composition, aerosol concentration, and particle size). Furthermore, the samples were analyzed with the newly developed UNAM-MOUDI-DFT device, allowing for the evaluation of the potential impact of different aerosol particles on mixed-phase cloud formation in the Yucatán Peninsula. This is the first such comprehensive study ever conducted in Mexico and among the first ones at tropical latitudes.

The three different air masses were found to contain INPs with different ice nucleating efficiencies. The cold fronts, responsible for advecting marine aerosol particles onto the Yucatán Peninsula in winter, were found to be an important source of efficient INPs. Out of the three aerosol types analyzed in the present study, marine aerosol particles were identified as having the highest $n_{\mathrm{s}}$ values and the warmest onset freezing temperatures. Therefore, this is the aerosol type with the highest potential to impact the local hydrological cycle. Although marine aerosol particles are ubiquitous in the Yucatán Peninsula since it is surrounded by the GoM and the Caribbean Sea, synoptic phenomena such as cold fronts and tropical cyclones may enhance their concentration and likely their organic content. Based on the present results, it is desirable to conduct similar measurements during the phytoplankton bloom season, under the influence of a tropical cyclone, and in October-November when there is a much lower probability of the occurrence of $\mathrm{BB}, \mathrm{AD}$, and cold fronts. 
In the absence of cold fronts, $\mathrm{AD}$ may be an important driver in mixed-phase cloud formation and, hence, in precipitation development. Given that these particles are not locally emitted, it is very important to improve the current understanding of the long-range transport of $\mathrm{AD}$ particles to Mexico, including their interannual variability.

Under the influence of all three air masses, supermicron particles were found to be the major contributor to the total INP concentrations. The present results highlight the importance of including the sampling of supermicron particles in future field measurements.

Data availability. The data from the present work can be found in the Supplement (Tables S3-S14). Also, they are available upon request to the corresponding author.

Supplement. The supplement related to this article is available online at: https://doi.org/10.5194/acp-21-4453-2021-supplement.

Author contributions. FC, GBR, and LAL designed the field campaigns and the experiments. FC, CRR, DC, WG, MG, AKB, and LAL built the UNAM-MOUDI-DFT. FC, CRR, HAO, DR, TA, BF, and LAL carried out the aerosol measurements. JM and HAO performed the chemical analyses. GBR, DB, DR, BF, JSK, JYH, and LAL installed the equipment and provided the infrastructure for the ADABBOY project. FC, CRR, and LAL wrote the paper with contributions from all coauthors.

Competing interests. The authors declare that they have no conflict of interest.

Acknowledgements. The authors thank Juan Carlos Pineda, Javier Juarez, Ivonne San Miguel, and Aline Cruz for their invaluable help. We also thank David S. Valdes from CINVESTAV Mérida for sharing the Sisal meteorological data and Sinsa Krytox for providing us with the Krytox lubricant. Finally, we thank the National Oceanic and Atmospheric Administration (NOAA) for facilitating the use of the surface maps and HYSPLIT.

Financial support. This research has been supported by the Consejo Nacional de Ciencia y Tecnología (grant nos. FC-2164 and CB-285023), the Dirección General de Asuntos del Personal Académico, Universidad Nacional Autónoma de México (grant no. PAPIIT IA108417), and the Facultad de Química, Universidad Autónoma de Yucatán (grant no. SISPROY-FQUI-2018-0003).

Review statement. This paper was edited by Thomas Koop and reviewed by two anonymous referees.

\section{References}

Ardon-Dryer, K. and Levin, Z.: Ground-based measurements of immersion freezing in the eastern Mediterranean, Atmos. Chem. Phys., 14, 5217-5231, https://doi.org/10.5194/acp-145217-2014, 2014.

Atkinson, J. D., Murray, B. J., Woodhouse, M. T., Whale, T. F., Baustian, K. J., Carslaw, K. S., Dobbie, S., O’Sullivan, D., and Malkin, T. L.: The importance of feldspar for ice nucleation by mineral dust in mixed-phase clouds, Nature, 498, 355-358, https://doi.org/10.1038/nature12278, 2013.

Augustin-Bauditz, S., Wex, H., Kanter, S., Ebert, M., Niedermeier, D., Stolz, F., Prager, A., and Stratmann, F.: The immersion mode ice nucleation behavior of mineral dusts: A comparison of different pure and surface modified dusts, Geophys. Res. Lett., 41, 7375-7382, https://doi.org/10.1002/2014GL061317, 2014.

Barnes, I., Hjorth, J., and Mihalopoulos, N.: Dimethyl sulfide and dimethyl sulfoxide and their oxidation in the atmosphere, Chem. Rev., 106, 940-975, https://doi.org/10.1021/cr020529+, 2006.

Beall, C. M., Lucero, D., Hill, T. C., DeMott, P. J., Stokes, M. D., and Prather, K. A.: Best practices for precipitation sample storage for offline studies of ice nucleation in marine and coastal environments, Atmos. Meas. Tech., 13, 6473-6486, https://doi.org/10.5194/amt-13-6473-2020, 2020.

Bigg, E.: Ice nucleus concentrations in remote areas, J. Atmos. Sci., 30, 1153-1157, https://doi.org/10.1175/15200469(1973)030<1153:INCIRA>2.0.CO;2, 1973.

Boose, Y., Sierau, B., García, M. I., Rodríguez, S., Alastuey, A., Linke, C., Schnaiter, M., Kupiszewski, P., Kanji, Z. A., and Lohmann, U.: Ice nucleating particles in the Saharan Air Layer, Atmos. Chem. Phys., 16, 9067-9087, https://doi.org/10.5194/acp-16-9067-2016, 2016.

Boucher, O., Randall, D., Artaxo, P., Bretherton, C., Feingold, G., Forster, P., Kerminen, V., Kondo, Y., Liao, H., Lohmann, U., Rasch, P., Satheesh, S., Sherwood, S., Stevens, B., and Zhang, X.: Clouds and Aerosols in Climate Change 2013: The Physical Science Basis, Contribution of Working Group I to IPCC AR5, edited by: Stocker, T. F., Qin, D., Plattner, G.-K., Tignor, M., Allen, S. K., Boschung, J., Nauels, A., Xia, Y., Bex, V., and Midgley, P. M., Cambridge University Press, Cambridge, United Kingdom and New York, NY, USA, 1535 pp., 2013.

Cavazos, T.: Downscaling large-scale circulation to local winter rainfall in north-eastern Mexico, Int. J. Climatol., 17, 1069-1082, https://doi.org/10.1002/(SICI)10970088(199708)17:10<1069::AID-JOC183>3.0.CO;2-I, 1997.

Creamean, J. M., Kirpes, R. M., Pratt, K. A., Spada, N. J., Maahn, M., de Boer, G., Schnell, R. C., and China, S.: Marine and terrestrial influences on ice nucleating particles during continuous springtime measurements in an Arctic oilfield location, Atmos. Chem. Phys., 18, 18023-18042, https://doi.org/10.5194/acp-1818023-2018, 2018.

DeMott, P. J., Sassen, K., Poellot, M. R., Baumgardner, D., Rogers, D. C., Brooks, S. D., Prenni, A. J., and Kreidenweis, S. M.: African dust aerosols as atmospheric ice nuclei, Geophys. Res. Lett., 30, 1732, https://doi.org/10.1029/2003GL017410, 2003.

DeMott, P. J., Prenni, A. J., Liu, X., Kreidenweis, S. M., Petters, M. D., Twohy, C. H., Richardson, M., Eidhammer, T., and Rogers, D.: Predicting global atmospheric ice nuclei distributions and their impacts on climate, P. Natl. Acad. Sci. USA, 107, 11217-11222, https://doi.org/10.1073/pnas.0910818107, 2010. 
DeMott, P. J., Hill, T. C., McCluskey, C. S., Prather, K. A., Collins, D. B., Sullivan, R. C., Ruppel, M. J., Mason, R, H., Irish, V. E., Lee, T., Hwang, C. Y., Rhee, T. S., Snider, J. R., McMeeking, G. R., Dhaniyala, S., Lewis, E. R., Wentzell, J. J., Abbatt, J., Lee, C., Sultana, C., Ault, A. P., Axson, J. L., Diaz Martinez, M., Venero, I., Santos-Figueroa, G., Stokes, M. D., Deane, G. B., MayolBracero, O. L., Grassian, V. H., Bertram, T. H., Bertram, A. K., Moffett, B. F., and Franc, G. D.: Sea spray aerosol as a unique source of ice nucleating particles, P. Natl. Acad. Sci. USA, 113, 5797-5803, https://doi.org/10.1073/pnas.1514034112, 2016.

DeMott, P. J., Hill, T. C., McCluskey, C. S., Prather, K. A., Collins, D. B., Sullivan, R. C., Ruppel, M. J., Mason, R, H., Irish, V. E., Lee, T., Hwang, C. Y., Rhee, T. S., Snider, J. R., McMeeking, G. R., Dhaniyala, S., Lewis, E. R., Wentzell, J. J., Abbatt, J., Lee, C., Sultana, C., Ault, A. P., Axson, J. L., Diaz Martinez, M., Venero, I., Santos-Figueroa, G., Stokes, M. D., Deane, G. B., Mayol-Bracero, O. L., Grassian, V. H., Bertram, T. H., Bertram, A. K. Moffett, B. F., and Franc, G. D.: Comparative measurements of ambient atmospheric concentrations of ice nucleating particles using multiple immersion freezing methods and a continuous flow diffusion chamber, Atmos. Chem. Phys., 17, 1122711245, https://doi.org/10.5194/acp-17-11227-2017, 2017.

DiMego, G. J., Bosart, L. F., and Endersen, G. W.: An examination of the frequency and mean conditions surrounding frontal incursions into the Gulf of Mexico and Caribbean Sea, Mon. Weather Rev., 104, 709-718, https://doi.org/10.1175/15200493(1976)104<0709:AEOTFA>2.0.CO;2, 1976.

Espinosa, A., Miranda, J., and Pineda, J.: Uncertainty evaluation in correlated quantities: application to elemental analysis of atmospheric aerosols, Rev. Mex. Fis., E56, 134-140, 2010.

Espinosa, A., Reyes-Herrera, J., Miranda, J., Mercado, F., Veytia, M., Cuautle, M., and Cruz, J.: Development of an X-ray fluorescence spectrometer for environmental science applications, Instrum. Sci. Technol., 40, 603-617, https://doi.org/10.1080/10739149.2012.693560, 2012.

García de Fuentes, A. and Morales, J.: Dinámica regional de Yucatán 1980-2000, Invest. Geográficas, 157-172, available at: http://www.scielo.org.mx/scielo.php?script=sci_arttext\&pid= S0188-46112000000200010\&lng=es\&nrm=iso (last access: 18 January 2020), 2000.

Gong, X., Wex, H., Müller, T., Wiedensohler, A., Höhler, K., Kandler, K., Ma, N., Dietel, B., Schiebel, T., Möhler, O., and Stratmann, F.: Characterization of aerosol properties at Cyprus, focusing on cloud condensation nuclei and icenucleating particles, Atmos. Chem. Phys., 19, 10883-10900, https://doi.org/10.5194/acp-19-10883-2019, 2019.

Gong, X., Wex, H., van Pinxteren, M., Triesch, N., Fomba, K. W., Lubitz, J., Stolle, C., Robinson, T.-B., Müller, T., Herrmann, H., and Stratmann, F.: Characterization of aerosol particles at Cabo Verde close to sea level and at the cloud level Part 2: Ice-nucleating particles in air, cloud and seawater, Atmos. Chem. Phys., 20, 1451-1468, https://doi.org/10.5194/acp20-1451-2020, 2020a.

Gong, X., Wex, H., Voigtländer, J., Fomba, K. W., Weinhold, K., van Pinxteren, M., Henning, S., Müller, T., Herrmann, H., and Stratmann, F.: Characterization of aerosol particles at Cabo Verde close to sea level and at the cloud level - Part 1: Particle number size distribution, cloud condensation nu- clei and their origins, Atmos. Chem. Phys., 20, 1431-1449, https://doi.org/10.5194/acp-20-1431-2020, 2020 b.

Griffin, D. W., Garrison, V. H., Herman, J. R., and Shinn, E. A.: African desert dust in the Caribbean atmosphere: microbiology and public health, Aerobiologia, 17, 203-213, https://doi.org/10.1023/A:1011868218901, 2001.

Guyon, P., Frank, G. P., Welling, M., Chand, D., Artaxo, P., Rizzo, L., Nishioka, G., Kolle, O., Fritsch, H., Silva Dias, M. A. F., Gatti, L. V., Cordova, A. M., and Andreae, M. O.: Airborne measurements of trace gas and aerosol particle emissions from biomass burning in Amazonia, Atmos. Chem. Phys., 5, 2989 3002, https://doi.org/10.5194/acp-5-2989-2005, 2005.

Harrison, A. D., Lever, K., Sanchez-Marroquin, A., Holden, M. A., Whale, T. F., Tarn, M. D., McQuaid, J. B., and Murray, B. J.: The ice-nucleating ability of quartz immersed in water and its atmospheric importance compared to K-feldspar, Atmos. Chem. Phys., 19, 11343-11361, https://doi.org/10.5194/acp-19-113432019, 2019.

Herrera-Silveira, J. A., Cirerol, N. A., Ghinaglia, L. T., Comín, F. A., and Madden, C.: Coastal eutrophication in the yucatán peninsula, Environ. Anal. Gulf Mex., 512-516, 2004 a.

Herrera-Silveira, J. A., Comin, F. A., Aranda-Cirerol, N., Troccoli, L., and Capurro, L.: Coastal water quality assessment in the Yucatan Peninsula: management implications, Ocean Coast. Manage., 47, 625-639, https://doi.org/10.1016/j.ocecoaman.2004.12.005, 2004b.

Iannone, R., Chernoff, D. I., Pringle, A., Martin, S. T., and Bertram, A. K.: The ice nucleation ability of one of the most abundant types of fungal spores found in the atmosphere, Atmos. Chem. Phys., 11, 1191-1201, https://doi.org/10.5194/acp-111191-2011, 2011.

INEGI: Principales resultados por localidad, Instituto Nacional de Estadistica y Geografia, Censo Poblacion y Vivienda, available at: http://www.beta.inegi.org.mx/app/geo2/ahl/ (last access: 18 January 2019), 2010.

INEGI: Principales resultados de la Encuesta Intercensal 2015 Yucatan, Instituto Nacional de Estadistica y Geografia, available at: http://www.internet.contenidos.inegi.org.mx/contenidos/ Productos/prod_serv/contenidos/espanol/bvinegi/productos/ nueva_estruc/702825078966.pdf (last access: 18 January 2019), 2015.

INEGI: Anuario estadistico y geogrifico de Yucatan 2017, Instituto Nacional de Estadistica y Geografia, available at: http://www. inegi.org.mx (last access: 18 January 2019), 2017.

INEGI: Informacion por Entididad Federativa, Instituto Nacional de Estadistica y Geografia, available at: http://www.cuentame.inegi.org.mx/monografias/informacion/ yuc/territorio/clima.aspx?tema $=$ me $\&$ e $=31 \quad$ (last access: 1 November 2019), 2019.

Irish, V. E., Elizondo, P., Chen, J., Chou, C., Charette, J., Lizotte, M., Ladino, L. A., Wilson, T. W., Gosselin, M., Murray, B. J., Polishchuk, E., Abbatt, J. P. D., Miller, L. A., and Bertram, A. K.: Ice-nucleating particles in Canadian Arctic sea-surface microlayer and bulk seawater, Atmos. Chem. Phys., 17, 10583-10595, https://doi.org/10.5194/acp-17-10583-2017, 2017.

Irish, V. E., Hanna, S. J., Willis, M. D., China, S., Thomas, J. L., Wentzell, J. J. B., Cirisan, A., Si, M., Leaitch, W. R., Murphy, J. G., Abbatt, J. P. D., Laskin, A., Girard, E., and Bertram, A. K.: Ice nucleating particles in the marine boundary layer in the 
Canadian Arctic during summer 2014, Atmos. Chem. Phys., 19, 1027-1039, https://doi.org/10.5194/acp-19-1027-2019, 2019.

Jahn, L. G., Polen, M. J., Jahl, L. G., Brubaker, T. A., Somers, J., and Sullivan, R. C.: Biomass combustion produces ice-active minerals in biomass-burning aerosol and bottom ash, P. Natl. Acad. Sci. USA, 117, 21928-21937, https://doi.org/10.1073/pnas.1922128117, 2020.

Jones, J., Darvell, L., Bridgeman, T., Pourkashanian, M., and Williams, A.: An investigation of the thermal and catalytic behaviour of potassium in biomass combustion, P. Combust. Inst., 31, 1955-1963, https://doi.org/10.1016/j.proci.2006.07.093, 2007.

Kaaden, N., Massling, A., Schladitz, A., Müller, T., Kandler, K., Schütz, L., Weinzierl, B., Petzold, A., Tesche, M., Leinert, S., Deutscher, C., Ebert, M., Weinbruch. S., and Wiedensohler. A.: State of mixing, shape factor, number size distribution, and hygroscopic growth of the Saharan anthropogenic and mineral dust aerosol at Tinfou, Morocco, Tellus B, 61, 51-63, https://doi.org/10.1111/j.1600-0889.2008.00388.x, 2009.

Kanji, Z. A., Ladino, L. A., Wex, H., Boose, Y., BurkertKohn, M., Cziczo, D. J., and Krämer, M.: Overview of ice nucleating particles, Meteor. Mon., 58, 1.1-1.33, https://doi.org/10.1175/AMSMONOGRAPHS-D-16-0006.1, 2017.

Kishcha, P., da Silva, A. M., Starobinets, B., Long, C. N., Kalashnikova, O., and Alpert, P.: Meridional distribution of aerosol optical thickness over the tropical Atlantic Ocean, Atmos. Chem. Phys. Discuss., 14, 23309-23339, https://doi.org/10.5194/acpd14-23309-2014, 2014.

Knopf, D., Alpert, P., Wang, B., and Aller, J.: Stimulation of ice nucleation by marine diatoms, Nat. Geosci., 4, 88-90, https://doi.org/10.1038/NGEO1037, 2011.

Kohn, M., Lohmann, U., Welti, A., and Kanji, Z. A.: Immersion mode ice nucleation measurements with the new Portable Immersion Mode Cooling chAmber (PIMCA), J. Geophys. Res., 121, 4713-4733, https://doi.org/10.1002/2016JD024761, 2016.

Koop, T., Luo, B., Tsias, A., and Peter, T.: Water activity as the determinant for homogeneous ice nucleation in aqueous solutions, Nature, 406, 611-614, https://doi.org/10.1029/2000JD900413, 2000.

Lacher, L., Adams, M., Barry, K., Bertozzi, B., Bras, Y., Boffo, C., Castarede, D., Cziczo, D. J., DeMott, P. J., Goodell, M., Höhler, K., Hill, T. C. J., Jentzsch, C., Ladino, L. A., Levin, E. J. T., Mertes, S., Möhler, O., Murray, B. J., Nadolny, J., Pfeuffer, T., Picard, D., Ramirez Romero, M. C., Ribeiro, M., Richter, S., Schrod, J., Sellegri, K., Stratmann, F., Thomson, E., Wex, H., Wolf, M., and Freney, E.: The Puy de Dôme Ice Nucleation Intercomparison (PICNIC): Comparison between online and offline freezing techniques in ambient air, in preparation, 2021.

Ladino, L. A., Raga, G. B., Alvarez-Ospina, H., Andino-Enríquez, M. A., Rosas, I., Martínez, L., Salinas, E., Miranda, J., RamírezDíaz, Z., Figueroa, B., Chou, C., Bertram, A. K., Quintana, E. T., Maldonado, L. A., García-Reynoso, A., Si, M., and Irish, V. E.: Ice-nucleating particles in a coastal tropical site, Atmos. Chem. Phys., 19, 6147-6165, https://doi.org/10.5194/acp19-6147-2019, 2019.

Ladino, L. A., Juarez-Perez, J., Ramirez-Diaz, Z., Miller, L. A., Herrera, J., Raga, G. B., Simpson, K. G., Cruz, G., Pereira, D. L., and Córdoba, F.: The UNAM-Droplet Freezing Assay:
An Evaluation of the Ice Nucleating Capacity of the SeaSurface Microlayer and Surface Mixed Layer in Tropical and Subpolar Waters (edited by Dr. Michel Grutter), Atmósfera, https://doi.org/10.20937/ATM.52938, in press, 2020.

Lee, C., Sultana, C. M., Collins, D. B., Santander, M. V., Axson, J. L., Malfatti, F., Cornwell, G. C., Grandquist, J. R., Deane, G. B., Stokes, M. D., Azam, F., Grassian, V. H., and Prather, K. A.: Advancing model systems for fundamental laboratory studies of sea spray aerosol using the microbial loop, J. Phys. Chem. A, 119, 8860-8870, https://doi.org/10.1021/acs.jpca.5b03488, 2015.

Levin, E., McMeeking, G., DeMott, P., McCluskey, C., Carrico, C., Nakao, S., Jayarathne, T., Stone, E., Stockwell, C., Yokelson, R., and Kreidenweis, S.: Ice-nucleating particle emissions from biomass combustion and the potential importance of soot aerosol, J. Geophys. Res., 121, 5888-5903, https://doi.org/10.1002/2016JD024879, 2016.

Li, J., Pósfai, M., Hobbs, P. V., and Buseck, P. R.: Individual aerosol particles from biomass burning in southern Africa: 2, Compositions and aging of inorganic particles, J. Geophys. Res.-Atmos., 108, 8484, https://doi.org/10.1029/2002JD002310, 2003.

Linke, C., Möhler, O., Veres, A., Mohácsi, Á., Bozóki, Z., Szabó, G., and Schnaiter, M.: Optical properties and mineralogical composition of different Saharan mineral dust samples: a laboratory study, Atmos. Chem. Phys., 6, 3315-3323, https://doi.org/10.5194/acp-6-3315-2006, 2006.

Lohmann, U. and Feichter, J.: Global indirect aerosol effects: a review, Atmos. Chem. Phys., 5, 715-737, https://doi.org/10.5194/acp-5-715-2005, 2005.

Lohmann, U., Lüönd, F., and Mahrt, F.: An introduction to clouds: From the microscale to climate, Cambridge University Press, Cambridge, UK, 2016.

Lüönd, F., Stetzer, O., Welti, A., and Lohmann, U.: Experimental study on the ice nucleation ability of size-selected kaolinite particles in the immersion mode, J. Geophys. Res., 115, D14201, https://doi.org/10.1029/2009JD012959, 2010.

Marcolli, C., Gedamke, S., Peter, T., and Zobrist, B.: Efficiency of immersion mode ice nucleation on surrogates of mineral dust, Atmos. Chem. Phys., 7, 5081-5091, https://doi.org/10.5194/acp7-5081-2007, 2007.

Mason, R. H., Chou, C., McCluskey, C. S., Levin, E. J. T., Schiller, C. L., Hill, T. C. J., Huffman, J. A., DeMott, P. J., and Bertram, A. K.: The micro-orifice uniform deposit impactordroplet freezing technique (MOUDI-DFT) for measuring concentrations of ice nucleating particles as a function of size: improvements and initial validation, Atmos. Meas. Tech., 8, 2449 2462, https://doi.org/10.5194/amt-8-2449-2015, $2015 \mathrm{a}$.

Mason, R. H., Si, M., Li, J., Chou, C., Dickie, R., Toom-Sauntry, D., Pöhlker, C., Yakobi-Hancock, J. D., Ladino, L. A., Jones, K., Leaitch, W. R., Schiller, C. L., Abbatt, J. P. D., Huffman, J. A., and Bertram, A. K.: Ice nucleating particles at a coastal marine boundary layer site: correlations with aerosol type and meteorological conditions, Atmos. Chem. Phys., 15, 12547-12566, https://doi.org/10.5194/acp-15-12547-2015, 2015 b.

Mason, R. H., Si, M., Chou, C., Irish, V. E., Dickie, R., Elizondo, P., Wong, R., Brintnell, M., Elsasser, M., Lassar, W. M., Pierce, K. M., Leaitch, W. R., MacDonald, A. M., Platt, A., ToomSauntry, D., Sarda-Estève, R., Schiller, C. L., Suski, K. J., Hill, T. C. J., Abbatt, J. P. D., Huffman, J. A., DeMott, P. J., and Bertram, A. K.: Size-resolved measurements of ice-nucleating 
particles at six locations in North America and one in Europe, Atmos. Chem. Phys., 16, 1637-1651, https://doi.org/10.5194/acp16-1637-2016, 2016.

McCluskey, C. S., DeMott, P. J., Prenni, A. J., Levin, E. J., McMeeking, G. R., Sullivan, A. P., Hill, T. C., Nakao, S., Carrico, C. M., and Kreidenweis, S. M.: Characteristics of atmospheric ice nucleating particles associated with biomass burning in the US: Prescribed burns and wildfires, J. Geophys. Res., 119, 10458-10470, https://doi.org/10.1002/2014JD021980, 2014.

McCluskey, C. S., Hill, T., Humphries, R., Rauker, A., Moreau, S., Strutton, P., Chambers, S., Williams, A., McRobert, I., Ward, J., Keywood, M. D., Harnwell, J., Ponsonby, W., Loh, Z. M., Krummel, P. B., Protat, A., Kreidenweis, S. M., and DeMott, P. J.: Observations of ice nucleating particles over Southern Ocean waters, Geophys. Res. Lett., 45, 11989-11997, https://doi.org/10.1029/2018GL079981, 2018.

Mülmenstädt, J., Sourdeval, O., Delanoë, J., and Quaas, J.: Frequency of occurrence of rain from liquid-, mixed-, and ice-phase clouds derived from A-Train satellite retrievals, Geophys. Res. Lett., 42, 6502-6509, https://doi.org/10.1002/2015GL064604, 2015.

Murray, B. J., Broadley, S. L., Wilson, T. W., Atkinson, J. D., and Wills, R. H.: Heterogeneous freezing of water droplets containing kaolinite particles, Atmos. Chem. Phys., 11, 4191-4207, https://doi.org/10.5194/acp-11-4191-2011, 2011.

Murray, B. J., O'Sullivan, D., Atkinson, J., and Webb, M.: Ice nucleation by particles immersed in supercooled cloud droplets, Chem. Soc. Rev., 41, 6519-6554, https://doi.org/10.1039/C2CS35200A, 2012.

Nagare, B., Marcolli, C., Welti, A., Stetzer, O., and Lohmann, U.: Comparing contact and immersion freezing from continuous flow diffusion chambers, Atmos. Chem. Phys., 16, 8899-8914, https://doi.org/10.5194/acp-16-8899-2016, 2016.

O’Dowd, C. D., Facchini, M. C., Cavalli, F., Ceburnis, D., Mircea, M., Decesari, S., Fuzzi, S., Yoon, Y. J., and Putaud, J.-P.: Biogenically driven organic contribution to marine aerosol, Nature, 431, 676-680, https://doi.org/10.1038/nature02959, 2004.

Ovadnevaite, J., Ceburnis, D., Leinert, S., Dall'Osto, M., Canagaratna, M., O'Doherty, S., Berresheim, H., and O'Dowd, C. D.: Submicron NE Atlantic marine aerosol chemical composition and abundance: Seasonal trends and air mass categorization, J. Geophys. Res.-Atmos., 119, 11850-11863, https://doi.org/10.1002/2013JD021330, 2014.

Parungo, F., Nagamoto, C., Rosinski, J., and Haagenson, P.: A study of marine aerosols over the Pacific Ocean, J. Atmos. Chem., 4, 199-226, https://doi.org/10.1007/BF00052001, 1986.

Peppler, R. A., Bahrmann, C., Barnard, J. C., Campbell, J., Cheng, M.-D., Ferrare, R., Halthore, R., Heilman, L., Hlavka, D., Laulainen, N. S., Lin, C.-J., Ogren., J. A., Poellot., M. R., Remer, L. A., Sassen, K., Spinhirne, J. D., Splitt, M. E., and Turner, D. D.: ARM Southern Great Plains site observations of the smoke pall associated with the 1998 Central American fires, B. Am. Meteorol. Soc., 81, 2563-2592, https://doi.org/10.1175/15200477(2000)081<2563:ASGPSO>2.3.CO;2, 2000.

Petters, M., Parsons, M., Prenni, A., DeMott, P., Kreidenweis, S., Carrico, C., Sullivan, A., McMeeking, G., Levin, E., Wold. C., Collett Jr., J. L., and Moosmüller, H.: Ice nuclei emissions from biomass burning, J. Geophys. Res.-Atmos., 114, D07209, https://doi.org/10.1029/2008JD011532, 2009.
Pósfai, M., Simonics, R., Li, J., Hobbs, P. V., and Buseck, P. R.: Individual aerosol particles from biomass burning in southern Africa: 1. Compositions and size distributions of carbonaceous particles, J. Geophys. Res., 108, 8483, https://doi.org/10.1029/2002jd002291, 2003.

Prather, K. A., Bertram, T. H., Grassian, V. H., Deane, G. B., Stokes, M. D., DeMott, P. J., Aluwihare, L. I., Palenik, B. P., Azam, F., Seinfeld, J. H., Moffet, R. C., Molina, M. J., Cappa, C. D., Geiger, F. M., Roberts, G. C., Russell, L. M., Ault, A. P., Baltrusaitis, J., Collins, D.B., Corrigan, C. E., Cuadra-Rodriguez, L. A., Ebben, C. J., Forestieri, S. D., Guasco, T. L., Hersey, S.P., Kim, M. J., Lambert, W.F., Modini, R. L., Mui, W., Pedler, B. E., Ruppel, M. J., Ryder, O. S., Schoepp, N. G., Sullivan, R. C., and Zhao, D.: Bringing the ocean into the laboratory to probe the chemical complexity of sea spray aerosol, P. Natl. Acad. Sci. USA, 110, 7550-7555, https://doi.org/10.1073/pnas.1300262110, 2013.

Prenni, A. J., Petters, M. D., Kreidenweis, S. M., Heald, C. L., Martin, S. T., Artaxo, P., Garland, R. M., Wollny, A. G., and Pöschl, U.: Relative roles of biogenic emissions and Saharan dust as ice nuclei in the Amazon basin, Nat. Geosci., 2, 402-405, https://doi.org/10.1038/ngeo517, 2009.

Prenni, A. J., DeMott, P. J., Sullivan, A. P., Sullivan, R. C., Kreidenweis, S. M., and Rogers, D. C.: Biomass burning as a potential source for atmospheric ice nuclei: Western wildfires and prescribed burns, Geophys. Res. Lett., 39, L11805, https://doi.org/10.1029/2012GL051915, 2012.

Price, H., Baustian, K., McQuaid, J., Blyth, A., Bower, K., Choularton, T., Cotton, R., Cui, Z., Field, P., Gallagher, M., Hawker, R., Merrington, A., Miltenberger, A., Neely III, R. R., Parker, S. T., Rosenberg, P. D., Taylor, J. W., Trembath, J., VergaraTemprado, J., Whale, T. F., Wilson, T. W., Young, G., and Murray, B. J.: Atmospheric Ice-Nucleating Particles in the Dusty Tropical Atlantic, J. Geophys. Res., 123, 2175-2193, https://doi.org/10.1002/2017JD027560, 2018.

Prospero, J. M. and Lamb, P. J.: African droughts and dust transport to the Caribbean: Climate change implications, Science, 302, 1024-1027, https://doi.org/10.1126/science.1089915, 2003.

Prospero, J. M. and Mayol-Bracero, O. L.: Understanding the transport and impact of African dust on the Caribbean basin, B. Am Meteorol. Soc., 94, 1329-1337, https://doi.org/10.1175/BAMSD-12-00142.1, 2013.

Pruppacher, H. and Klett, J.: Microphysics of Clouds and Precipitation, D. Reidel Publishing Company, Dordrecht, the Netherlands, 954 pp., 1997.

Querol, X., Tobías, A., Pérez, N., Karanasiou, A., Amato, F., Stafoggia, M., García-Pando, C. P., Ginoux, P., Forastiere, F., Gumy, S., Mudu, P., and Alastuey, A.: Monitoring the impact of desert dust outbreaks for air quality for health studies, Environ. Int., 130, 104867, https://doi.org/10.1016/j.envint.2019.05.061, 2019.

Quinn, P. K., Collins, D. B., Grassian, V. H., Prather, K. A., and Bates, T. S.: Chemistry and related properties of freshly emitted sea spray aerosol, Chem. Rev., 115, 4383-4399, https://doi.org/10.1021/cr500713g, 2015.

Raga, G. B., Ladino, L. A., Baumgardner, D., Ramirez-Romero, C., Cordoba, F., Alvarez-Ospina, H., Rosas, D., Amador, T., Miranda, J., Rosas, I., Jaramillo, A., Yakobi-Hancock, J., Kim, J., Martínez, L., Salinas, E., and Figueroa, B.: African Dust and 
Biomass Burning over Yucatan, B. Am. Meteorol. Soc., in review, 2021.

Ramírez-Romero, C., Jaramillo, A., Córdoba, M. F., Raga, G. B., Miranda, J., Alvarez-Ospina, H., Rosas, D., Amador, T., Kim, J. S., Yakobi-Hancock, J., Baumgardner, D., and Ladino, L. A.: African dust particles over the western Caribbean - Part I: Impact on air quality over the Yucatán Peninsula, Atmos. Chem. Phys., 21, 239-253, https://doi.org/10.5194/acp-21-239-2021, 2021.

Reicher, N., Budke, C., Eickhoff, L., Raveh-Rubin, S., KaplanAshiri, I., Koop, T., and Rudich, Y.: Size-dependent ice nucleation by airborne particles during dust events in the eastern Mediterranean, Atmos. Chem. Phys., 19, 11143-11158, https://doi.org/10.5194/acp-19-11143-2019, 2019.

Reid, J. S., Koppmann, R., Eck, T. F., and Eleuterio, D. P.: A review of biomass burning emissions part II: intensive physical properties of biomass burning particles, Atmos. Chem. Phys., 5, 799825, https://doi.org/10.5194/acp-5-799-2005, 2005.

Ríos, B. and Raga, G. B.: Spatio-temporal distribution of burned areas by ecoregions in Mexico and Central America, Int. J. Remote Sens., 39, 949-970, https://doi.org/10.1080/01431161.2017.1392641, 2018.

Rodriguez-Gomez, C., Ramirez-Romero, C., Cordoba, F., Raga, G. B., Salinas, E., Martinez, L., Rosas, I., Quintana, E. T., Maldonado, L. A., Rosas, D., Amador, T., Alvarez, H., and Ladino, L. A.: Characterization of culturable airborne microorganisms in the Yucatan Peninsula, Atmos. Environ., 223, 117183, https://doi.org/10.1016/j.atmosenv.2019.117183, 2020.

Rosinski, J., Haagenson, P., Nagamoto, C., and Parungo, F.: Nature of ice-forming nuclei in marine air masses, J. Aerosol Sci., 18, 291-309, https://doi.org/10.1016/0021-8502(87)90024-3, 1987.

Rosinski, J., Haagenson, P., Nagamoto, C., Quintana, B., Parungo, F., and Hoyt, S.: Ice-forming nuclei in air masses over the Gulf of Mexico, J. Aerosol Sci., 19, 539-551, https://doi.org/10.1016/0021-8502(88)90206-6, 1988.

Saarikoski, S., Sillanpää, M., Sofiev, M., Timonen, H., Saarnio, K., Teinilä, K., Karppinen, A., Kukkonen, J., and Hillamo, R.: Chemical composition of aerosols during a major biomass burning episode over northern Europe in spring 2006: Experimental and modelling assessments, Atmos. Environ., 41, 3577-3589, https://doi.org/10.1016/j.atmosenv.2006.12.053, 2007.

Saide, P., Spak, S., Pierce, R., Otkin, J., Schaack, T., Heidinger, A., Da Silva, A., Kacenelenbogen, M., Redemann, J., and Carmichael, G.: Central American biomass burning smoke can increase tornado severity in the US, Geophys. Res. Lett., 42, 956-965, https://doi.org/10.1002/2014GL062826, 2015.

Santoyo, A.: Esbozo Monográfico de Sisal, Yucatán, Open File Rep., Laboratorio Nacional de Resilencia Costera, Sisal, Yucatán, 2017.

Schnell, R. and Vali, G.: Freezing nuclei in marine waters, Tellus A, 27, 321-323, https://doi.org/10.1111/j.21533490.1975.tb01682.x, 1975.

Si, M., Irish, V. E., Mason, R. H., Vergara-Temprado, J., Hanna, S. J., Ladino, L. A., Yakobi-Hancock, J. D., Schiller, C. L., Wentzell, J. J. B., Abbatt, J. P. D., Carslaw, K. S., Murray, B. J., and Bertram, A. K.: Ice-nucleating ability of aerosol particles and possible sources at three coastal marine sites, Atmos. Chem. Phys., 18, 15669-15685, https://doi.org/10.5194/acp-18-156692018, 2018.
Taylor, D. A.: Dust in the wind, Environ. Health Persp., 110, 80-87, https://doi.org/10.1289/ehp.110-a80, 2002.

Trujano-Jiménez, F., Ríos, B., Jaramillo, A., Ladino, L. A., and Raga, G. B.: The impact of biomass burning emissions on protected natural areas in central and southern Mexico, Environ. Sci. Pollut. R., https://doi.org/10.1007/s11356-020-12095-y, in press, 2021.

Umo, N. S., Murray, B. J., Baeza-Romero, M. T., Jones, J. M., Lea-Langton, A. R., Malkin, T. L., O’Sullivan, D., Neve, L., Plane, J. M. C., and Williams, A.: Ice nucleation by combustion ash particles at conditions relevant to mixed-phase clouds, Atmos. Chem. Phys., 15, 5195-5210, https://doi.org/10.5194/acp15-5195-2015, 2015.

Vali, G.: Quantitative evaluation of experimental results an the heterogeneous freezing nucleation of supercooled liquids, J. Atmos. Sci., 28, 402-409, https://doi.org/10.1175/15200469(1971)028<0402:QEOERA>2.0.CO;2, 1971.

Welti, A., Lüönd, F., Kanji, Z. A., Stetzer, O., and Lohmann, U.: Time dependence of immersion freezing: an experimental study on size selected kaolinite particles, Atmos. Chem. Phys., 12, 9893-9907, https://doi.org/10.5194/acp-12-9893-2012, 2012.

Welti, A., Müller, K., Fleming, Z. L., and Stratmann, F.: Concentration and variability of ice nuclei in the subtropical maritime boundary layer, Atmos. Chem. Phys., 18, 5307-5320, https://doi.org/10.5194/acp-18-5307-2018, 2018.

Welti, A., Bigg, E. K., DeMott, P. J., Gong, X., Hartmann, M., Harvey, M., Henning, S., Herenz, P., Hill, T. C. J., Hornblow, B., Leck, C., Löffler, M., McCluskey, C. S., Rauker, A. M., Schmale, J., Tatzelt, C., van Pinxteren, M., and Stratmann, F.: Ship-based measurements of ice nuclei concentrations over the Arctic, Atlantic, Pacific and Southern oceans, Atmos. Chem. Phys., 20, 15191-15206, https://doi.org/10.5194/acp-20-151912020, 2020.

Wex, H., Huang, L., Zhang, W., Hung, H., Traversi, R., Becagli, S., Sheesley, R. J., Moffett, C. E., Barrett, T. E., Bossi, R., Skov, H., Hünerbein, A., Lubitz, J., Löffler, M., Linke, O., Hartmann, M., Herenz, P., and Stratmann, F.: Annual variability of ice-nucleating particle concentrations at different Arctic locations, Atmos. Chem. Phys., 19, 5293-5311, https://doi.org/10.5194/acp-19-5293-2019, 2019.

Wheeler, M., Mason, R., Steunenberg, K., Wagstaff, M., Chou, C., and Bertram, A.: Immersion freezing of supermicron mineral dust particles: Freezing results, testing different schemes for describing ice nucleation, and ice nucleation active site densities, J. Phys. Chem. A, 119, 4358-4372, https://doi.org/10.1021/jp507875q, 2015.

Wilbourn, E. K., Thornton, D. C., Ott, C., Graff, J., Quinn, P. K., Bates, T. S., Betha, R., Russell, L. M., Behrenfeld, M. J., and Brooks, S. D.: Ice nucleation by marine aerosols over the North Atlantic Ocean in late spring, J. Geophys. Res., 125, e2019JD030913, https://doi.org/10.1029/2019JD030913, 2020.

Wilson, T. W., Ladino, L. A., Alpert, P. A., Breckels, M. N., Brooks, I. M., Browse, J., Burrows, S. M., Carslaw, K. S., Huffman, J. A., Judd, C., Kilthau, W. P., Mason, R.H., McFiggans, G., Miller, L. A., Nájera, J. J. Polishchuk, E., Rae, S., Schiller, C. L., Si, M., Vergara Temprado, J., Whale, T. F., Wong, J. P., Wurl, O., Yakobi-Hancock, J. D., Abbatt, J. P., Aller, J. Y., Bertram, A. K., Knopf, D. A., and Murray, B. J.: A marine biogenic source 
of atmospheric ice-nucleating particles, Nature, 525, 234-238, https://doi.org/10.1038/nature14986, 2015.

Wu, P.-C., Tsai, J.-C., Li, F.-C., Lung, S.-C., and Su, H.-J.: Increased levels of ambient fungal spores in Taiwan are associated with dust events from China, Atmos. Environ., 38, 4879-4886, https://doi.org/10.1016/j.atmosenv.2004.05.039, 2004.

Xia, L. and Gao, Y.: Chemical composition and size distributions of coastal aerosols observed on the US East Coast, Mar. Chem., 119, 77-90, https://doi.org/10.1016/j.marchem.2010.01.002, 2010.

Yakobi-Hancock, J. D., Ladino, L. A., and Abbatt, J. P.: Review of Recent Developments and Shortcomings in the Characterization of Potential Atmospheric Ice Nuclei: Focus on the Tropics, Rev. Cienc., 17, 15-34, https://doi.org/10.25100/rc.v17i3.476, 2014.

Yoch, D. C.: Dimethylsulfoniopropionate: its sources, role in the marine food web, and biological degradation to dimethylsulfide, Appl. Environ. Microb., 68, 5804-5815, https://doi.org/10.1128/AEM.68.12.5804, 2002.

Yokelson, R. J., Crounse, J. D., DeCarlo, P. F., Karl, T., Urbanski, S., Atlas, E., Campos, T., Shinozuka, Y., Kapustin, V., Clarke, A. D., Weinheimer, A., Knapp, D. J., Montzka, D. D., Holloway, J., Weibring, P., Flocke, F., Zheng, W., Toohey, D., Wennberg, P. O., Wiedinmyer, C., Mauldin, L., Fried, A., Richter, D., Walega, J., Jimenez, J. L., Adachi, K., Buseck, P. R., Hall, S. R., and Shetter, R.: Emissions from biomass burning in the Yucatan, Atmos. Chem. Phys., 9, 5785-5812, https://doi.org/10.5194/acp-9-57852009, 2009.
Zhang, H., Hu, D., Chen, J., Ye, X., Wang, S. X., Hao, J. M., Wang, L., Zhang, R., and An, Z.: Particle size distribution and polycyclic aromatic hydrocarbons emissions from agricultural crop residue burning, Environ. Sci. Technol., 45, 5477-5482, https://doi.org/10.1021/es1037904, 2011.

Zimmermann, F., Weinbruch, S., Schütz, L., Hofmann, H., Ebert, M., Kandler, K., and Worringen, A.: Ice nucleation properties of the most abundant mineral dust phases, J. Geophys. Res., 113, D23204, https://doi.org/10.1029/2008JD010655, 2008. 